Article

\title{
Agricultural Expansion in the Brazilian Cerrado: Increased Soil and Nutrient Losses and Decreased Agricultural Productivity
}

\author{
Luciene Gomes ${ }^{1, * \mathbb{C}}$, Silvio J. C. Simões ${ }^{2}$, Eloi Lennon Dalla Nora ${ }^{3}$, \\ Eráclito Rodrigues de Sousa-Neto ${ }^{3}\left(\mathbb{D}\right.$, Maria Cristina Forti ${ }^{3}$ and Jean Pierre H. B. Ometto ${ }^{3}$ \\ 1 School of Geography, Faculty of Environment, University of Leeds, Leeds LS2 9JT, UK \\ 2 Department of Environmental Engineering, São Paulo State University (UNESP), São José dos Campos \\ 12245-000, Brazil; silvio.simoes@ict.unesp.br \\ 3 Earth System Science Centre (CCST), National Institute for Space Research (INPE), São José dos Campos \\ 12227, Brazil; eloidalla84@yahoo.com.br (E.L.D.N.); eraklito@gmail.com (E.R.d.S.-N.); \\ cristina.forti@inpe.br (M.C.F.); jean.ometto@inpe.br (J.P.H.B.O.) \\ * Correspondence: L.Gomes@leeds.ac.uk; Tel.: +44-0-113-3437994
}

Received: 27 September 2018; Accepted: 3 January 2019; Published: 8 January 2019

\begin{abstract}
While food and nutrition security are issues that national and international organizations are tackling, one of the central problems often overlooked is the essential role of soils in providing nutritious food. Soils are the base for food production and food security. However, the majority of soils are in fair and poor conditions, with the most significant threats being erosion and loss of nutrients. In this study, we estimate the potential of soil loss, agricultural productivity loss, and nutrient loss for Brazil's most important agricultural region, the Brazilian Cerrado, for the years 2000 and 2012. For this, we applied the Revised Universal Soil Loss Equation (RUSLE) model integrated with a geographical information system (GIS) to estimate annual soil loss rate and agricultural productivity loss, and used total nitrogen and total phosphorus in soil to estimate the annual nutrient loss rate caused by soil loss. All model factors and data were obtained from the literature. The results show that agricultural expansion in the Brazilian Cerrado is increasing the area of severe erosion, occasioning agricultural productivity decrease and soil nutrient depletion. The annual soil loss rate increased from 10.4 (2000) to $12.0 \mathrm{Mg} \mathrm{ha}^{-1} \mathrm{yr}^{-1}$ (2012). Agricultural productivity loss occurred in more than 3 million hectares of crops and silviculture in 2000 and in more than 5.5 million hectares in 2012. Severely eroded areas lost between 13.1 and 25.9 times more nutrients than areas with low and moderate soil loss rates. These findings show that government policy should be directed to ensure the sustainable use of soils, mainly in agriculturally consolidated regions of the Brazilian Cerrado.
\end{abstract}

Keywords: soil erosion; land use change; food production; food security; crop productivity; nitrogen; phosphorus; Brazil; RUSLE; GIS

\section{Introduction}

Food and nutrition security are issues that national and international organizations are dealing with (e.g., the Food and Agriculture Organization, FAO) in the face of economic and population growth. However, one crucial problem that is often overlooked is the essential role of soils in providing nutritious food [1-3]. Soils are the base for food production and food security, as about $95 \%$ of global food is produced from soil. However, the majority of soils are in fair and poor conditions, with accelerated erosion and loss of nutrients being the most significant threats [4-6].

Accelerated erosion is when soil losses take place much faster than new soil can be created through natural processes of decay and regeneration. This is a form of land degradation which leads to the 
removal of topsoil by water and/or wind in soil disturbed by intensive cultivation and/or grazing [4]. Topsoil contains most of the plant-essential micro- and macro-nutrients, as well as organic matter, and is responsible for soil structural stability. Therefore, by reducing the thickness of topsoil, accelerated erosion also alters soil properties and impacts soil nutrient dynamics. Nitrogen and phosphorus are readily mobilized with the topsoil particles, including both their organic and inorganic forms $[6,7]$. Soil erosion has been shown to lead to a decrease in plant productivity of $8 \%$ [8] to $80 \%$ [9] compared to pre-erosion conditions or uneroded control soils [6].

During erosion processes, particles are detached from the soil and exposed to lateral movement. In this phase, soil aggregation is disrupted, exposing organic matter (including nitrogen) that had previously been physically protected inside aggregates to loss by the transport of dissolved or particulate forms. The transport phase renders organic matter and inorganic ions of nitrogen (nitrate, $\mathrm{NO}_{3}{ }^{-}$, and ammonium, $\mathrm{NH}_{4}{ }^{+}$) more prone to leaching, thereby increasing their loss from the eroding soil [7]. Similarly, phosphorus is also lost during the transport phase of erosion in both dissolved (as phosphate, $\mathrm{PO}_{4}{ }^{2-}$ ) and particulate (as both organic and inorganic $\mathrm{P}$ bound to soil minerals) phases [6]. However, most of the phosphorus that is mobilized laterally via transport in particulate forms through surface runoff binds with soil particles, such as calcium, iron, and aluminium cations $[4,6]$. Soil erosion governs the biogeochemical properties of nutrients, and, unless balanced by an increased rate of nutrient input, can lead to the limitation of nutrients for plants and reduced rates of plant productivity [6,7].

Accelerated erosion and nutrient loss vary between soils and ecoregions, and depend on slope, soil management, cropping systems, soil conservation measures, and technological inputs $[2,3,10,11]$. In the tropics, the risk of soil erosion is potentially high due to the natural factors of this region [10]. For example, the large amount and high intensity of rainfall strongly influence erosive processes $[10,11]$. Additionally, tropical soils, with a few exceptions, are structurally unstable. They slake readily under the impact of raindrops and desiccate quickly following intense storms, causing a surface crust that severely decreases the infiltration rate. These structural alterations are accentuated in soils which lack the protective cover of vegetation or are improperly managed [10]. According to [4], the rate of soil erosion by water in tropical regions can exceed $20 \mathrm{tha}^{-1} \mathrm{yr}^{-1}$.

Tropical regions have also been identified as the natural candidate to allocate increasing food production to meet global demand, due to their climate, which is favorable for increasing productivity per area per year, and high availability of arable land [12-14]. Currently, Brazil is the second largest global supplier of food and agricultural products, and the country is poised to take leadership when responding to additional global demand [15]. This good performance has been credited to investments in Brazil's "tropical agriculture" and the expansion of its agricultural production into the Brazilian savanna (Cerrado) [16].

Presently, the Cerrado is responsible for 70\% of Brazil's agricultural production [17]. It accounts for $95 \%$ of the total cotton, $54 \%$ of soybean, $55 \%$ of beef, and $43 \%$ of sugarcane produced in Brazil [18], and also plays an important role in the production of bioenergy from sugarcane and eucalyptus planted forests $[19,20]$. However, the Cerrado is also an area of serious land degradation due to accelerated erosion by water; this is followed by a loss of nutrients, which poses a significant threat to food security. Agricultural expansion for the production of commodities is leading to severe erosion of arable land, nutrient loss, some overgrazing, environmental problems, and loss of biodiversity [21]. Thus, the Cerrado deserves particular policy attention and recommendations to protect and improve the quality of its agricultural soils [21].

Many models for predicting erosion have been developed and applied as tools for soil loss assessment, conservation planning, policy recommendation, and land use decision making [22-24]. Of these models, the Universal Soil Loss Equation (USLE) [25] and Revised Universal Soil Loss Equation (RUSLE) [26], are the most frequently used. The advantages of these methods are their simplicity, the effectiveness of their equations, their success in predicting long-term soil loss with acceptable accuracy, and their low financial requirements [27]. Additionally, when integrated into a 
geographic information system (GIS), these models are capable of estimating soil loss and its spatial distribution, especially for large areas. The outputs of the RUSLE model have also been used as a tool to estimate the loss of agricultural productivity [8] and nutrients [28,29] from water erosion. However, it is important to highlight that the RUSLE model is not able to reproduce reality [30]. Modeling in general, and large-scale modeling in particular, does not aim at an accurate prediction of point measurements, but rather tests hypotheses on process understanding, relative spatial and temporal variations, and controlling factors $[30,31]$. Thus, RUSLE can be a helpful tool to policymakers when applied to the Cerrado.

Little is known about how the loss of soil, nutrients, and agricultural productivity has changed over the years in the Cerrado [32-37]. Some studies of soil loss have been made on the medium to small scale or in plots [32,33,35-37]; however, they do not give an overview of degraded soils in a large ecosystem scale or point out the main activities that cause soil degradation. Studies which consider a geospatial analysis, including applications using GIS, remote sensing, and the RUSLE model are sparse and cover limited areas within the Cerrado. The RUSLE model was applied by [32] for the Goiás State and Federal District. The study emphasized degraded pasture as one of the major environmental and economic problems for livestock production. Studying a smaller area, [33] used RUSLE for modeling erosion in a watershed occupied by rural settlement in the Cerrado. Both [32] and [33] show a significant increase in the potential for erosion due to changes in vegetation and land use when compared with the natural potential for erosion. No studies were found that use the RUSLE model, or that consider the relationship between spatial erosion and agricultural productivity, for the entire Brazilian Cerrado.

Few studies exist on the potential decrease in productivity caused by water erosion [38]. Additionally, little data exists on nutrient dynamics in eroding landscapes, despite the importance of nutrients for primary production [35]. Therefore, taking into account those reasons and addressing the challenge of food security, soil degradation, and the importance of the Cerrado for meeting future agricultural production, the main goal of this study is to obtain an overview of the loss of soil, agricultural productivity, and nutrients caused by water erosion in the Brazilian Cerrado between 2000 and 2012. This is the first study that combines research on the loss of soil, agricultural productivity, and soil nutrients at the whole-Cerrado scale over time. To reach this objective, the specific goals of this study were to: (1) estimate the potential soil loss in agricultural lands of the Cerrado regions in the years 2000 and 2012 by using RUSLE together with a GIS; (2) estimate the loss of agricultural productivity based on the estimation of soil loss in 2000 and 2012; (3) estimate the potential loss of nitrogen and phosphorus based on the estimation of soil loss in 2000 and 2012; and (4) identify regions for soil conservation where the loss of soil, nutrients, and agricultural productivity can be high.

\section{Study Area}

The Cerrado encompasses approximately 2 million $\mathrm{km}^{2}$ of the Brazilian Central Plateau (24\% of the country's total area) (Figure 1). The region is transitional with the Amazon rainforest, Caatinga, Pantanal, and Atlantic Forest [39], being considered as one of the richest and most diverse savannas in the world [40]. The Cerrado is considered one of the 35 global biodiversity hotspots [41] due to the high level of endemism and rapid habitat loss caused by fire regimes and agricultural expansion [42]. 

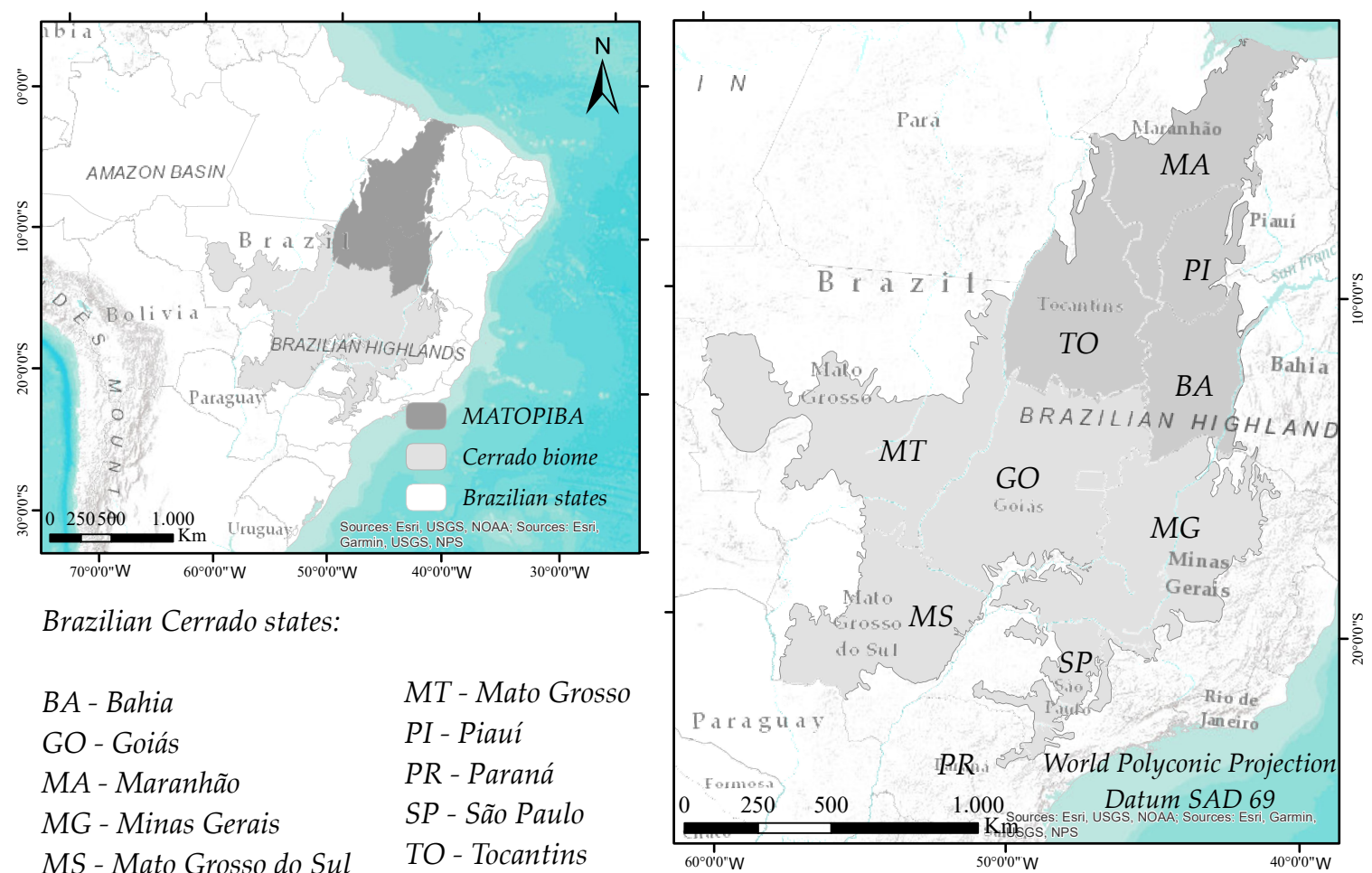

Brazilian Cerrado states:

$\begin{array}{ll}\text { BA - Bahia } & \text { MT - Mato Grosso } \\ \text { GO - Goiás } & \text { PI - Piauí } \\ \text { MA - Maranhão } & \text { PR - Paraná } \\ \text { MG - Minas Gerais } & \text { SP - São Paulo } \\ \text { MS - Mato Grosso do Sul } & \text { TO - Tocantins }\end{array}$

Figure 1. Location of the study area. The Brazilian Cerrado encompasses totally or partially the states of Bahia (BA), Goiás (GO), Maranhão (MA), Minas Gerais (MG), Mato Grosso do Sul (MS), Mato Grosso (MT), Piauí (PI), Paraná (PR), São Paulo (SP), and Tocantins (TO).

The Cerrado corresponds to a large diversified landscape consisting mainly of grassland (campo limpo), grassland with scattered trees (campo sujo), savanna (cerrado, strict sense), and woodland (cerradão) [43]. The climate is characterized by distinct wet and dry seasons of relatively equal duration, with annual precipitation ranging from 800 to $1800 \mathrm{~mm}$. There is a large variety in the rainfall distribution, with more than $70 \%$ of precipitation falling in the rainy season, which occurs in November to April. The smallest amount of precipitation falls in the northeastern part of the region [44,45]. The average annual temperature varies from 20 to $26{ }^{\circ} \mathrm{C}$ [43]. Soil types are predominantly Ferralsols ( 41\%), Arenosols ( 15\%), Acrisols ( 12\%), and Plinthosols ( 10\%) [46]. These soils are highly weathered and have low contents of organic matter and nutrients, especially nitrogen and phosphorus [47]. The relief is mostly flat with areas of gentle hills [48].

Brazilian governmental programs have encouraged the occupation and economic development of the country's central region, leading to the intensification of land use change in the Cerrado [49]. Consequently, by 2013, 46\% (95 Mha) of the Cerrado's native vegetation cover had been deforested and turned into pasture and areas of mechanized agriculture [50]. By some estimates, only $20 \%$ of the region remains undisturbed and a mere $8 \%$ is preserved in protected areas. To make matters worse, the Cerrado is now home to the newest Brazilian agricultural frontier, named MATOPIBA —an acronym formed from the first two letters of Maranhão (MA), Tocantins (TO), Piauí (PI), and Bahia (BA) states. This most frontier has been characterized by rapid changes in land cover and land use for agricultural expansion [51]. For example, during the 2005-2014 period, the area used for soy crops in MATOPIBA increased by $86 \%$, while the increase at the national level was $29 \%$ [52,53].

\section{Methods}

A brief description of input data and the soil erosion model (RUSLE) and its biophysical and anthropic parameters are given below. Next, we present the agricultural productivity and nutrient loss methodologies that were used to quantify the impacts of water soil erosion in agricultural lands. Other 
forms of erosion (harvest erosion, gully erosion, wind erosion, etc.) are not considered here. Finally, we present the statistical analyses applied to analyze the main parameters contributing to erosion in different areas of the Cerrado, such as erosivity, erodibility, topography, cover management, and supporting practices.

\subsection{Input Data and Pre-Processing}

All input data for the RUSLE model were stored, analyzed, and visualized within the ArcGIS ${ }^{\circledR}$ environment (version 10.6). The GIS database was georeferenced using the World Polyconic projection and SAD 69 (South American Datum 1969). The full database is presented in Table 1.

Table 1. Georeferenced input data applied in the Revised Universal Soil Loss Equation (RUSLE) model for the Brazilian Cerrado.

\begin{tabular}{cccccc}
\hline No. & Data & Data Format & Resolution (m) & Scale & Source \\
\hline 1 & Erosivity map & Raster & 2822 & $1: 5,000,000$ \\
2 & Soil map & Vector & - & $1: 5,000,000$ \\
3 & Digital Elevation Model (DEM) & Raster & 94 & $1: 100,000$ \\
4 & 2000 and 2012 Land Use and Cover Maps & Vector & - & $1: 5,000,000$ & {$[46]$} \\
\hline
\end{tabular}

The Land Use and Cover Maps for both 2000 and 2012 have 14 different land use and land cover units, which were reclassified in order to represent the classes of interest as follows:

(a) Agriculture class: agriculture areas, a mosaic of agricultural areas with remaining forest, a mosaic of forest vegetation with agricultural areas, and a mosaic of grassland with agricultural areas;

(b) Pasture: planted and managed pastureland (e.g., cattle-ranching);

(c) Silviculture: planted and managed forests with exotic species (e.g., eucalyptus, pines);

(d) Natural vegetation: includes natural vegetation in different stages of ecological succession (e.g., forest vegetation, grassland, and wetland);

(e) Others: artificial areas (e.g., urbanized zones, road systems, non-agricultural systems), continental water bodies, coastal water bodies, and uncovered lands (e.g., rock outcrops and sand dunes).

The Agriculture unit was split into three classes in an attempt to separate agricultural areas from forest vegetation and grassland: annual (grains), semi-perennial (sugarcane), and perennial (coffee). For this purpose, the Agriculture unit was multiplied by spatially explicit data of grains [56,57], sugarcane [58], and coffee [59]. As a result, Annual, Semi-perennial and Perennial agricultural units were obtained, while residues were reclassified as Natural vegetation. Therefore, the final maps comprise seven land-use units: Pasture, Natural vegetation, Forestry, Annual crops, Semi-perennial crops, Perennial crops, and Others.

\subsection{Revised Universal Soil Loss Equation (RUSLE) Model}

The estimations of soil loss and its spatial distribution were obtained using the RUSLE model integrated with the GIS. RUSLE is an empirical mathematical model developed to estimate water soil erosion [26]. The evolution and improvement of the USLE led to the development of the RUSLE computer program $[25,26]$. In the same way as its predecessor, the model does not estimate sediment deposition on slopes [60], but only establishes an estimate of the average annual soil loss caused by rill and interrill erosion [61]. The RUSLE model estimates the potential soil loss rates, which indicate the intensity of the erosion processes. The model is a product of five factors, according to Equation (1):

$$
\mathrm{A}=\mathrm{R} \times \mathrm{K} \times \mathrm{LS} \times \mathrm{C} \times \mathrm{P}
$$

where $\mathrm{A}$ is the annual average soil loss per unit area $\left(\mathrm{tha}^{-1} \mathrm{yr}^{-1}\right), \mathrm{R}$ is the rainfall-runoff erosivity factor (MJ mm ha $\left.{ }^{-1} \mathrm{~h}^{-1} \mathrm{yr}^{-1}\right), \mathrm{K}$ is the soil erodibility factor $\left(\mathrm{t} \mathrm{h} \mathrm{MJ} \mathrm{Jm}^{-1} \mathrm{~mm}^{-1}\right.$, LS is the slope length and slope steepness factor (dimensionless), $\mathrm{C}$ is the crop management factor (dimensionless), and 
$\mathrm{P}$ is the erosion control practice factor (dimensionless). After integration with the GIS, soil erosion loss was calculated on a cell-by-cell basis in order to recognize the spatial patterns of soil loss. Thus, each factor was calculated taking grid cells of $94 \times 94 \mathrm{~m}$ as reference. The spatial distribution of soil erosion loss was produced by multiplying all factor layers to produce a final map. In order to avoid the interference of outliers in the model due to the influence of topographic variation in the study area, we performed a percentile analysis where $95 \%$ (two standard deviations) of the soil loss pixels values were considered in the analysis and $5 \%$ of the soil loss pixels values were considered as outliers.

The methodological approach followed in RUSLE is detailed in the simplified flowchart depicted in Figure 2.

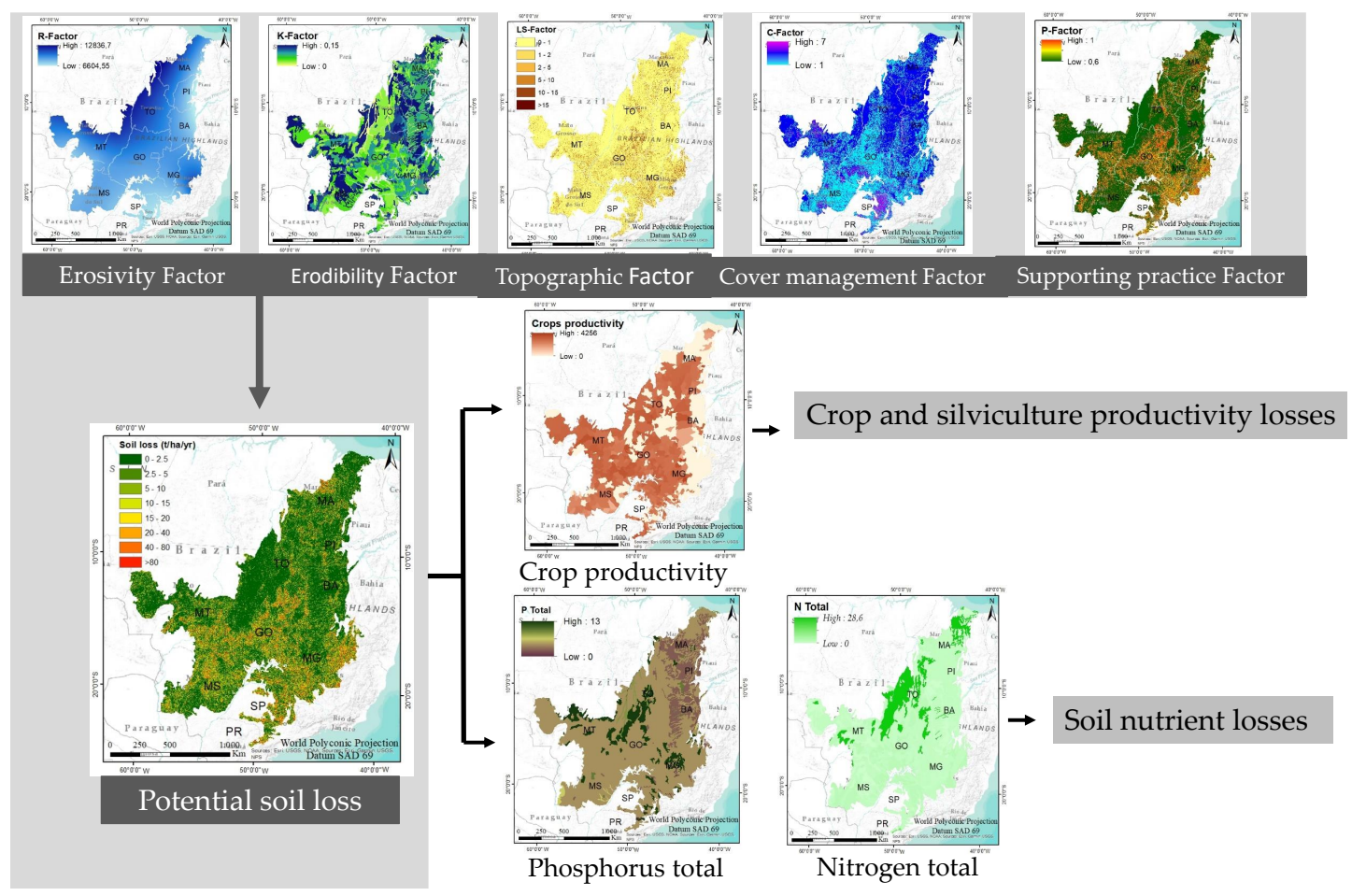

Figure 2. Flowchart of the methodology used to estimate the average rate of soil loss, agricultural productivity loss, and nutrient loss for the Brazilian Cerrado using the RUSLE model integrated into a GIS.

\subsubsection{Rainfall-Runoff Erosivity Factor (R)}

The rainfall-runoff erosivity factor (R-factor) represents the erosive power of precipitation in a given soil, regolith, or other weathered material. Precipitation is the driving force of erosion and has a direct effect on different phases of erosional processes including the detachment of soil particles, the breakdown of aggregates, and the transport of eroded material by runoff. The R-factor is the kinetic energy of raindrops that fall onto the ground and is affected by rainfall intensity and raindrop size [26].

\subsubsection{Soil Erodibility Factor (K)}

The soil erodibility factor (K-factor) is a property that depends upon two factors: the first one is the infiltration capacity to resist the detachment and transportation by rainfall, and the second one is the runoff process [62]. Therefore, $\mathrm{K}$-factor values reflect the rate of soil loss per rainfall-runoff erosivity (R) index for a specific soil [26]. The K-factor varies from zero to one, with a value of zero referring to soils with less susceptibility to water erosion and a value of one referring to soils with higher susceptibility to water erosion [63]. A K-factor map was produced based on the soil map and erodibility values published in several studies conducted in different areas of Brazil for the same soil types. The K-factor values for each soil type in the Brazilian Cerrado are given in Table 2. 
Table 2. Soil classification for the Brazilian Cerrado and soil erodibility $(K)$ values and their respective sources.

\begin{tabular}{|c|c|c|c|c|c|}
\hline No. & Brazilian Soil Classification & $\begin{array}{c}\text { Food and Agriculture } \\
\text { Organization (FAO) } \\
\text { Classification }\end{array}$ & Area $(\%)$ & $\underset{\left(t h \mathrm{MJ}^{-1} \mathrm{~mm}^{-1}\right)}{\mathrm{K}}$ & Source \\
\hline 1 & Latossolos Vermelhos Distróficos & Ferralsols & 15.37 & 0.018 & [64] \\
\hline 2 & Neossolos Quartzarênicos Órticos & Arenosols & 14.22 & 0.056 & [65] \\
\hline 3 & Latossolos Amarelos Distróficos & Ferralsols & 11.40 & 0.028 & [64] \\
\hline 4 & Latossolos Vermelho-Amarelos Distróficos & Ferralsols & 9.59 & 0.011 & [66] \\
\hline 5 & Cambissolos Háplicos Tb Distróficos & Cambisols & 7.87 & 0.036 & [67] \\
\hline 6 & Neossolos Litólicos Distróficos & Leptosols & 7.60 & 0.050 & [68] \\
\hline 7 & Plintossolos Pétricos Concrecionarios & Plinthosols & 6.19 & 0.012 & [68] \\
\hline 8 & Argissolos Vermelho-Amarelos Distróficos & Acrisols & 5.87 & 0.047 & [64] \\
\hline 9 & Latossolos Vermelhos Distroférricos & Ferralsols & 4.06 & 0.012 & [68] \\
\hline 10 & Plintossolos Háplicos Distróficos & Plinthosols & 4.02 & 0.055 & [64] \\
\hline 11 & Argissolos Vermelhos Eutróficos & Acrisols & 2.84 & 0.031 & [65] \\
\hline 12 & Argissolos Vermelho-Amarelos Eutróficos & Acrisols & 2.15 & 0.051 & [64] \\
\hline 13 & Gleissolos Háplicos Tb Distróficos & Gleysols & 1.52 & 0.001 & [68] \\
\hline 14 & Cambissolos Háplicos Ta Eutróficos & Cambisols & 1.42 & 0.039 & [64] \\
\hline 15 & Argissolos Vermelhos Distróficos & Acrisols & 1.04 & 0.055 & [69] \\
\hline 16 & Neossolos Flúvicos & Fluvisols & 0.56 & 0.046 & [64] \\
\hline 18 & Neossolos Litólicos Eutróficos & Leptosols & 0.43 & 0.036 & [64] \\
\hline 19 & Planossolos Nátricos Órticos & Solonetz & 0.42 & 0.057 & [64] \\
\hline 20 & Nitossolos Vermelhos Distróficos & Nitisols & 0.37 & 0.011 & [64] \\
\hline 21 & Chernossolos Argiluvicos Órticos & Chernozems & 0.35 & 0.010 & [70] \\
\hline 22 & Luvissolos Crômicos Pálicos & Luvisols & 0.32 & 0.247 & [66] \\
\hline 23 & Nitossolos Vermelhos Eutróficos & Nitisols & 0.27 & 0.011 & [64] \\
\hline 24 & Neossolos Regolíticos Distróficos & Regosols & 0.23 & 0.050 & [68] \\
\hline 25 & Chernossolos Rendzicos Órticos & Chernozems & 0.23 & 0.010 & [70] \\
\hline 26 & Planossolos Háplicos Distróficos & Haplics & 0.20 & 0.057 & [64] \\
\hline 27 & Planossolos Háplicos Eutróficos & Haplics & 0.18 & 0.057 & {$[64]$} \\
\hline 28 & Neossolos Quartzarênicos Hidromórficos & Arenosols & 0.16 & 0.046 & [64] \\
\hline 29 & Latossolos Vermelhos Eutroférricos & Ferralsols & 0.13 & 0.010 & [69] \\
\hline 30 & Gleissolos Sálicos Sodicos & Gleysols & 0.08 & 0.001 & [68] \\
\hline 31 & Luvissolos Crômicos Órticos & Luvisols & 0.08 & 0.247 & {$[66]$} \\
\hline 32 & Cambissolos Húmicos Distróficos & Cambisols & 0.07 & 0.043 & {$[66]$} \\
\hline 34 & Vertissolos Háplicos Órticos & Vertisols & 0.06 & 0.040 & [71] \\
\hline 35 & Latossolos Vermelho-Amarelos Distroférricos & Ferralsols & 0.06 & 0.011 & [66] \\
\hline 37 & Gleissolos Háplicos Ta Distróficos & Gleysols & 0.02 & 0.001 & [68] \\
\hline 38 & Vertissolos Ebânicos Carbonaticos & Vertisols & 0.02 & 0.040 & [71] \\
\hline 39 & Organossolos Háplicos Hêmicos & Histosols & 0.01 & 0.061 & [70] \\
\hline 40 & Other (water, dunes and rocks) & - & 0.56 & - & - \\
\hline
\end{tabular}

\subsubsection{Topographic Factor (LS)}

The topographic factor (LS-factor) represents the influence of the relief on the erosion process [26]. The LS-factor depends on the slope steepness (S) and slope length (L) considering slopes as uniform profiles. In general, soil erosion increases as the slope steepness increases due to increased runoff flow velocity. Additionally, soil erosion increases as slope length increases due to the rising accumulation of runoff on the downslope [20]. Maximum slope length is seldom longer than $600 \mathrm{ft}(182.88 \mathrm{~m})$ or shorter than 15-20 ft (4.57-6.10 m) [72]. Both parameters are obtained from a digital elevation model (DEM) considering different approaches and methods [73]. This study was based on [73], which calculated the L-factor using as reference the upslope contributing area of each cell according to Equation (2):

$$
L i, j=\frac{\left[\left(A i, j-i n+D^{2}\right)^{m+1}-(A i, j-i n)^{m+1}\right]}{\left[D^{m+2} \times x i, j^{m} \times(22,13)^{m}\right]},
$$

where $L i, j$ is the slope length factor for the grid cell with coordinates $(i, j), A i, j-i n$ is the contributing area at the inlet of the grid cell with coordinates $(i, j)\left(\mathrm{m}^{2}\right), D$ is the grid cell size $(\mathrm{m}), m$ is a dimensionless exponent that depends on slope steepness (S), and $x i, j$ is the flow direction value for the grid cell with coordinate $(i, j)$. The exponent $m$ was calculated according to [25] being $S<1 \%, m=0.2 ; 1 \% \leq \mathrm{S} \leq 3 \%$, $m=0.3 ; 3 \%<\mathrm{S} \leq 5 \%, m=0.4 ;$ and $\mathrm{S}>5 \%, m=0.5$. 
The slope steepnes (S-factor) was calculated based on [74], according to Equations (3) and (4):

$$
\begin{aligned}
& S=10.8 * \sin \theta+0.03 \text { for slopes }<9 \%, \\
& S=16.8 * \sin \theta-0.50 \text { for slopes } \geq 9 \%,
\end{aligned}
$$

where $\theta$ is the slope radian (rad). Slope steepness was divided into six categories based on [75], as depicted in Table 3.

Table 3. Slope steepness categories for the Brazilian Cerrado by [75].

\begin{tabular}{ccc}
\hline Categories (\%) & Relief Classification & Area (\%) \\
\hline $0-3$ & Flat reliefs & 89.98 \\
$3-8$ & Gentle hillslope & 8.88 \\
$8-13$ & Gentle to moderate hillslope & 0.99 \\
$13-20$ & Strongly undulating relief & 0.14 \\
$20-45$ & Mountain with steep hillslope & 0.01 \\
$45-100$ & Ridge escarpments & 0.00 \\
\hline
\end{tabular}

\subsubsection{Cover and Management Factor (C)}

The cover and management factor (C-factor) represents an integration of several factors that affect erosion, including vegetative cover, plant litter, soil surface, and land management $[25,26]$. This is the second most important factor in RUSLE, after topography, since it represents the conditions that can be easily changed to reduce overland flow and soil erosion [63]. Although treated as an independent variable in Equation (1), this factor depends upon other factors. The C-factor varies from near zero (for a good erosion protection) to one (for a poor erosion protection) [76]. As mentioned before, in this work seven land use classes for the Brazilian Cerrado were considered: Pasture, Natural vegetation, Silviculture, Annual crops, Semi-perennial crops, Perennial crops, and Others. The C-factor values extracted from the literature and the percentage of the area to each land use are presented in Table 4.

Table 4. Values of the cover management factor (C) for each land use cover class of the Brazilian Cerrado.

\begin{tabular}{cccccc}
\hline No. & Land Use & $\begin{array}{c}\text { Area (\%) } \\
\mathbf{2 0 0 0}\end{array}$ & $\begin{array}{c}\text { Area (\%) } \\
\mathbf{2 0 1 2}\end{array}$ & C & Source \\
\hline 1 & Pasture & 36.79 & 40.76 & 0.05 & {$[38,77]$} \\
2 & Natural Vegetation & 55.36 & 47.31 & 0.01 & {$[78]$} \\
3 & Silviculture & 0.80 & 0.91 & 0.12 & {$[79,80]$} \\
4 & Annual crops & 4.75 & 7.34 & 0.08 & {$[81,82]$} \\
5 & Semi-perennial crops & 0.88 & 2.05 & 0.31 & {$[83]$} \\
6 & Perennial crops & 0.32 & 0.47 & 0.11 & {$[84]$} \\
7 & Others & 1.09 & 1.16 & 0.00 & - \\
\hline
\end{tabular}

\subsubsection{Supporting Practice Factor $(\mathrm{P})$}

The effect of erosion control practice (P-factor) represents the relationship between soil loss with a specific support practice and the corresponding loss with up-down slope cultivation [26]. The P-factor varies according to soil conservation practices, and thus has a strong influence on soil loss. Practices characterized by the P-factor include strip-cropping and terracing which are not applicable to the most forested region [26]. Since the soil conservation practices for each system cannot be known for the entire Brazilian Cerrado, where an area of about $880,000 \mathrm{~km}^{2}$ is occupied by farmland, the P-factor values were determined according to [85], and applied as in [86-88], which calculated this factor based on slope radian $(\theta)$. Thus, the P-factor was calculated to be 0.6 for $0 \leq \theta \leq 5 \%, 0.69947-0.08991 * \theta+$ $0.01184 * \theta^{2}-0.00035 * \theta^{3}$ for $5 \%<\theta \leq 20 \%$ and 1.0 for $\theta>20 \%$. 


\subsection{Crop Productivity Loss (CPL) Estimation}

Loss of agricultural productivity in the Brazilian Cerrado was also estimated using the outputs of the RUSLE model. Based on [8], we assumed that a crop productivity loss of $8 \%$ occurs in agricultural fields cultivated with high erosion rates $\left(>11 \mathrm{tha}^{-1} \mathrm{yr}^{-1}\right)$. According to the literature, the productivity loss caused by erosion can reach $80 \%$ [6]. Therefore, here we assumed a conservative value of $8 \%$, according to [8], due to the lack of data for the Brazilian Cerrado region. As fertilizers are used in most agricultural lands, we did not consider any productivity loss in agricultural fields that have low and moderate soil loss rates $\left(<11 \mathrm{t} \mathrm{ha}^{-1} \mathrm{yr}^{-1}\right)$, because fertilizers may compensate low and moderate productivity losses. Thus, the rate of crop productivity loss due to water erosion was estimated according to [8], as in Equation (5):

$$
C P L_{i}=S E A_{i}^{*} 0.08 \times C P_{i}
$$

where $C P L_{i}$ is the crop productivity loss (tonnes) where $i$ represent the crops, $S E A_{i}$ is the area of severe erosion (ha), and $C P_{i}$ is the crop productivity $\left(\mathrm{t} \mathrm{ha}^{-1}\right)$. The crop productivity loss was calculated for the years 2000 and 2012. Values of crop and silviculture productivity were based on data from the Brazilian Institute for Geography and Statistics [89,90] and the Statistical Yearbook of the Brazilian Association of Planted Forest Producers (ABRAF) [91,92]. Soy and maize represented $37.9 \%$ and $35.0 \%$ of annual crop area in 2000 and $52.0 \%$ and $31.2 \%$ in 2012 , respectively [18,93]. The crop productivity loss was calculated for soy and maize, as well as for a semi-perennial crop (sugarcane) and a perennial crop (coffee). We did not measure soil productivity loss in pasture lands due to a lack of data for grass production. We do not consider that the number of head of cattle per ha is a direct measurement of productivity loss in pasture lands.

\subsection{Nitrogen (N) and Phosphorus (P) Potential Loss Estimation}

Nutrient loss in the Brazilian Cerrado was estimated using the outputs of the RUSLE model. As the addition of fertilizer alone cannot compensate for all the nutrients lost when the topsoil erodes [4], in this study we only considered the loss of nutrients inherent to each type of soil and did not take into account the loss of nutrients from fertilizer application. We used nutrient values from topsoil ( 0 to $20 \mathrm{~cm}$ depth). The nitrogen values for each soil type of the Cerrado are based on [94]. The values of phosphorus are based on [95]. We estimate the loss of nitrogen $(N)$ and phosphorus $(P)$ in the soils according to $[28,29]$, as follows:

$$
\begin{gathered}
N=A \times T O T N, \\
P=A \times T O T P,
\end{gathered}
$$

where $N$ and $P$ are the estimates of nitrogen $\left(\mathrm{kg} \mathrm{ha}^{-1}\right)$ and phosphorus $\left(\mathrm{g} \mathrm{ha}^{-1}\right)$, respectively, in the soil erosion, $A$ is the soil erosion rate $\left(\mathrm{t} \mathrm{ha}^{-1} \mathrm{yr}^{-1}\right)$, and TOTN and TOTP are soil total nitrogen (in kilograms of $N$ ) and total phosphorus (grams of $P$ ) per kilogram of soil, respectively. We are aware that connecting nutrients and crop productivity is a complex task given that crop productivity depends on several factors, such as plant genotype, pest control, available water, association with microorganisms, agricultural management, and many others. Therefore, here we estimated nitrogen and phosphorus potential loss as just one of the factors that can affect agricultural productivity.

\subsection{Statistical Analysis}

We conducted a statistical method based on the principal component analysis (PCA) that uses a mathematical procedure that transforms a number of (possibly) correlated variables into a (smaller) number of uncorrelated variables named principal components $[96,97]$. In other words, PCA is a dimension-reduction tool that can be used to reduce a large set of variables to a small set that still contains most of the information in the large set. In this study, PCA was used to assess the contribution 
of the individual components (R-factor, K-factor, L-factor, S-factor, C-factor, P-factor) on the magnitudes of erosion considering four regions within the Cerrado for the years 2000 and 2012. For that, we used the software Statgraphics Centurion $\mathrm{XV}^{\circledR}$, version 15.2.00. PCA includes calculation of eigenvalues and their corresponding eigenvectors of the covariance matrix to produce the new variables in decreasing rank of importance to describe variation in the original variables [96,97]. A principal component matrix representing the transformation of coefficients (calculated from the covariance matrix), and a set of principal components (PCs) is obtained as the output $[96,97]$. Therefore, each output PC has different information that is uncorrelated with other PCs. PCA with Varimax rotation was performed to identify the PCs with the purpose to enhance the interpretability of their components. However, only PCs with eigenvalues of 0.9 or more were considered.

\section{Results and Discussion}

We present the estimation of potential soil losses in the Cerrado for the years 2000 and 2012. The estimation of agricultural productivity losses is described in the second Section 4.2. The following sections present the estimations of potential nutrient losses and priority areas for soil conservation. The final section presents the limitations of this study.

\subsection{Potential Soil Loss in the Brazilian Cerrado and Its Spatial Distribution}

Soil loss in the Brazilian Cerrado increased over time. In 2000, the average soil loss was $10.4 \mathrm{t} \mathrm{ha}^{-1}$ $\mathrm{yr}^{-1}$ and in 2012 it was $12.0 \mathrm{t} \mathrm{ha}^{-1} \mathrm{yr}^{-1}$. The main cause of this increase was the expansion of agricultural land. Table 5 presents the categories of soil loss for the entire Brazilian Cerrado, and Figure 3 presents the spatial distribution of these soil loss categories. Table 6 presents the average soil loss by pasture, silviculture, and annual, semi-perennial, and perennial crops, and Figure 4 presents the hotspot of change in soil loss between 2000 and 2012.

Table 5. Intervals of soil losses simulated for the land use conditions (entire Cerrado) in 2000 and 2012 on the Brazilian Cerrado.

\begin{tabular}{|c|c|c|c|c|c|}
\hline \multirow{2}{*}{$\begin{array}{l}\text { Soil Loss Interval } \\
\left(\mathrm{t} \mathrm{ha}^{-1} \mathrm{yr}^{-1}\right)\end{array}$} & \multirow{2}{*}{$\begin{array}{l}\text { Soil Erosion } \\
\text { Categories }\end{array}$} & Area (1000 ha) & Area $(\%) *$ & Area (1000 ha) & Area $(\%) *$ \\
\hline & & \multicolumn{2}{|c|}{2000} & \multicolumn{2}{|c|}{2012} \\
\hline $0-2.5$ & \multirow{2}{*}{ Slight } & 1221.62 & 56.08 & 1147.82 & 52.69 \\
\hline $2.5-5$ & & 313.87 & 14.41 & 325.30 & 14.93 \\
\hline $5-10$ & Moderate & 249.86 & 11.47 & 265.92 & 12.21 \\
\hline $10-15$ & \multirow{2}{*}{ High } & 112.22 & 5.15 & 121.78 & 5.59 \\
\hline $15-20$ & & 64.39 & 2.96 & 70.61 & 3.24 \\
\hline $20-40$ & Very high & 111.10 & 5.10 & 123.95 & 5.69 \\
\hline $40-80$ & Severe & 60.91 & 2.80 & 69.76 & 3.20 \\
\hline$>80$ & Very severe & 44.30 & 2.03 & 53.13 & 2.44 \\
\hline
\end{tabular}

\footnotetext{
* The area of the Brazilian Cerrado is about 2,178,271.15 ha.
} 


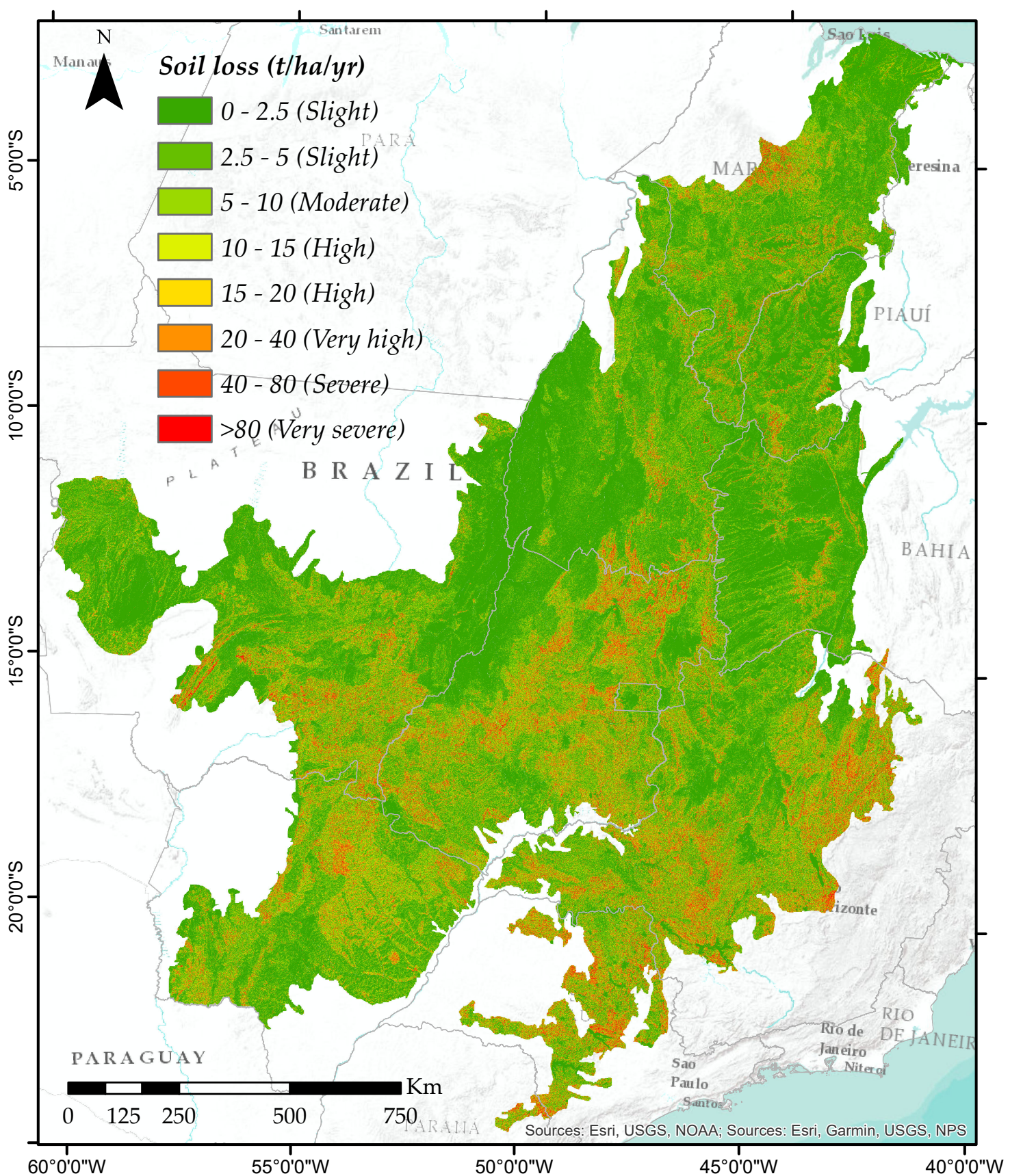

Figure 3. Map of potential soil loss rate $\left(\mathrm{t} \mathrm{ha}^{-1} \mathrm{yr}^{-1}\right)$ in the Brazilian Cerrado (reference year: 2012).

Table 6. Simulated potential soil loss $\left(\mathrm{t} \mathrm{ha}^{-1} \mathrm{yr}^{-1}\right)$ for the agricultural land use of the Brazilian Cerrado for the years 2000 and 2012.

\begin{tabular}{|c|c|c|c|}
\hline \multirow{2}{*}{ Land Use Cover } & \multicolumn{2}{|c|}{ Potential Soil Loss $\left(\mathrm{t} \mathrm{ha}^{-1} \mathrm{yr}^{-1}\right)$} & \multirow{2}{*}{ Soil Loss Class } \\
\hline & 2000 & 2012 & \\
\hline Pasture & 14.25 & 14.94 & High \\
\hline Silviculture & 33.76 & 38.69 & Very high \\
\hline Annual crops & 11.42 & 11.86 & High \\
\hline Semi-perennial crops & 45.35 & 46.54 & Severe \\
\hline Perennial crops & 31.11 & 32.83 & Very high \\
\hline
\end{tabular}




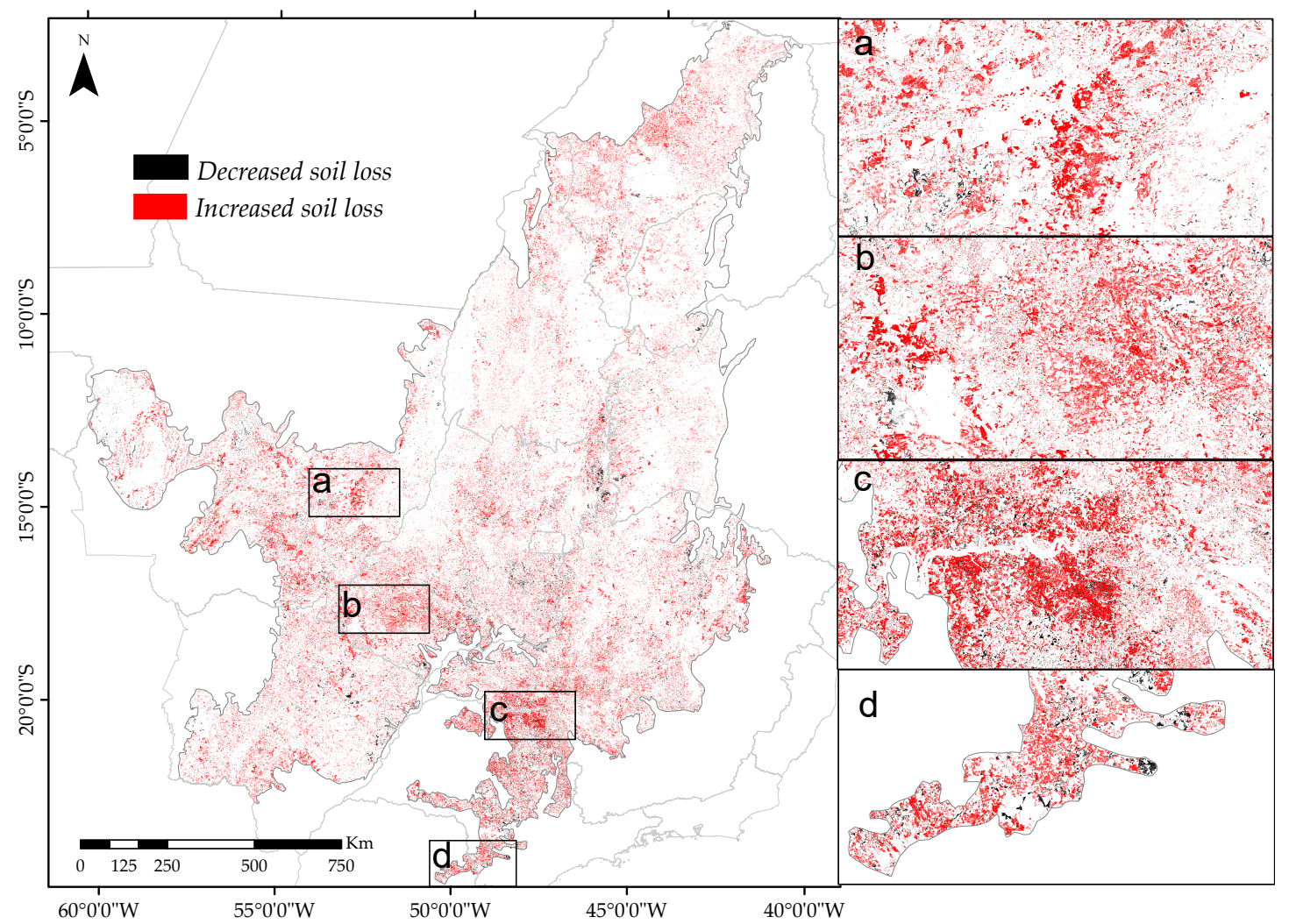

Figure 4. Map of changes in soil loss between 2000 and 2012 in the Brazilian Cerrado. Red areas indicate that soil loss increased from 2000 to 2012, while black areas indicate that soil loss decreased from 2000 to 2012. In both areas $\mathbf{a}$ and $\mathbf{b}$, there was a predominance of annual crops expansion; in $\mathbf{c}$ area, there was a prevalence of semi-perennial crop expansion; and in $\mathbf{d}$ area, there was a predominance of silviculture expansion.

The results show that about $70.5 \%(1,535,487 \mathrm{ha})$ of the Cerrado was in the category of slight erosion in 2000 (Table 5). This category continued to dominate in 2012, accounting for $67.6 \%(1,473,120$ ha); however, it showed a reduction of 62,367 ha as a consequence of the increased soil loss. Between 2000 and 2012, the area in the categories of moderate, high, very high, severe, and very severe erosion increased by $0.7 \%$ ( $16,052 \mathrm{ha}), 0.7 \%$ (15,775 ha), $0.6 \%$ (12,854 ha), $0.4 \%$ (8849 ha) and $0.4 \%$ (8837 ha), respectively. Figure 3 shows that the areas that are most vulnerable to very high $\left(20-40 \mathrm{tha}^{-1} \mathrm{yr}^{-1}\right)$,

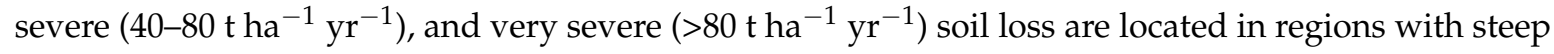
slopes (i.e., high LS-factor). However, some areas where crops and silviculture are located also show high values of soil loss. Consequently, the increase in soil loss between 2000 and 2012 can be partly attributed to agricultural expansion and the reduction of natural vegetation (Table 4), as soil loss has a close relationship with the type of land use cover.

All agricultural lands are classified in the high, very high, and severe soil loss categories, with their soil loss rates increasing over the period between 2000 and 2012, as shown in Table 6. Semi-perennial crops, silviculture, and perennial crops have the highest rates of soil loss, and presented increases in soil loss rates of $2.6 \%, 14.6 \%$, and $5.5 \%$ in this period, respectively. These crops presented a high land cover management factor (C-factor) due to conventional tillage. Additionally, in some states of the Cerrado, such as São Paulo (SP) and Minas Gerais (MG) (Figure 3), some semi-perennial, silviculture, and perennial crop lands are located in regions above $12 \%$ of slope, which represents lands with a strong susceptibility to erosion [98]. Annual crops and pasture have the lowest rates of soil loss, with increases in soil loss rate of $3.9 \%$ and $4.8 \%$, respectively. The low rates are due to the reduced land 
cover management factor (C-factor) for these uses, especially for annual crops where reduced or absent tillage practices are applied.

Figure 4 shows the hotspot of soil loss changes in the Brazilian Cerrado. Red areas indicate areas where the soil loss increased from 2000 to 2012 and black areas indicate areas where the soil loss decreased from 2000 to 2012. These results show that the increase in soil loss occurred in areas where agriculture and pasture lands expanded between 2000 and 2012. Although the highest soil losses are observed in regions with steep slope and some areas of crops and silviculture (Figure 3), as mentioned above, the new areas where the soil loss increased are located where agricultural lands expanded. In Figure 4, it is possible to see four different areas: $a, b, c$, and $d$. In both areas $a$ and $b$, there was a predominance of annual crop expansion; in area $c$, there was a prevalence of semi-perennial crop expansion; and in area $d$, there was a predominance of silviculture expansion. These four areas are located in the agricultural consolidated region (states of Mato Grosso, Mato Grosso do Sul, Goiás, Minas Gerais, São Paulo, and Paraná), where the change in soil loss was greater. In general, about $89.6 \%$ (1,951,730 ha) of the Cerrado area in 2000 showed no change in soil loss relative to 2012. The area in which increased soil loss was observed accounted for about 6.2\% (135,052 ha) of the Cerrado area, and the area in which decreased soil loss was observed accounted for $1.9 \%(41,387 \mathrm{ha})$. These results suggest that soil loss in the Cerrado is increasing.

The purpose of the PCA was to obtain a small number of factors which account for most of the variability in the six components of soil erosion (R-factor, K-factor, L-factor, S-factor, C-factor, and P-factor). The PCA results were applied for the areas $a, b, c$, and $d$ (Figure 4 ) and indicated four principal factors with eigenvalues greater than 0.9 (Table 7). These factors together account for a cumulative variance of 54.3\% (2000) and 56.3\% (2012) for area $a, 54.0 \%$ (2000) and 53.2\% (2012) for area $b$, and $51.9 \%$ (2000) and 49.7\% (2012) for area $d$. The order of significance of these components is determined by the magnitude of their eigenvalues (Table 7). Unlike the three areas mentioned above, for the area $c$, the results were not statistically significant with regard to the proportionality among the factors.

The variables considered in the PCA and their factors loadings within their respective PCs are presented in Table 8. In general, for the areas $a, b$ and $d$, the most significant variables that contribute to water erosion are erodibility (K-factor), cover management (C-factor) and erosivity (R-factor). In area $a$, the most important variables were erodibility reaching a value of 0.72 (PC 1) in 2000 and cover management reaching a value of 0.96 (PC 1) in 2012. These results are due to $67.7 \%$ of area $a$ is formed by soil with high erodibility (above $0.05 \mathrm{t} \mathrm{h} \mathrm{MJ}^{-1} \mathrm{~mm}^{-1}$ ). In addition, the annual crops area showed very significant growth from $1.7 \%$ of the total area to $48 \%$ for the period $2000-2012$. In area $b$, the cover management was also the most important variable that contributed to erosion reaching a value of 0.94 (PC 1) in both years (2000 and 2012). This area also reflects the growth of annual crops area rising from $23 \%$ of the total area in 2000 to $85 \%$ in 2012 . In area $d$, the most relevant variables were erosivity reaching a value of 0.90 (PC 1) in 2000 and 0.91 (PC 1) in 2012 and erodibility reaching a value of 0.84 (PC 1) in 2000 and 0.76 (PC 1) in 2012. These results clearly reflect the erodibility variation between 0.2 and $0.5 \mathrm{t} \mathrm{h} \mathrm{MJ}^{-1} \mathrm{~mm}^{-1}$ and erosivity of $7800 \mathrm{MJ} \mathrm{mm} \mathrm{ha}{ }^{-1} \mathrm{~h}^{-1} \mathrm{yr}^{-1}$ in area $d$. In general, PCA analyses were reasonable to show significant variables that contribute most with erosion processes in the selected areas. These analyses are important because they can indicate the best agricultural management practice to be applied regionally according to the characteristic of each area. 
Table 7. Principal components (PCs) for the areas $a, b$, and $d$ of the Brazilian Cerrado.

\begin{tabular}{|c|c|c|c|}
\hline \multirow{2}{*}{$\begin{array}{l}\text { Principal Component } \\
\text { (PC) }\end{array}$} & Eigenvalue & Variance $(\%)$ & Cummulative Variance $(\%)$ \\
\hline & \multicolumn{3}{|c|}{ Area $a-2000$} \\
\hline 1 & 1.52 & 16.92 & 16.92 \\
\hline 2 & 1.34 & 14.90 & 31.82 \\
\hline 3 & 1.02 & 11.32 & 43.14 \\
\hline 4 & 1.00 & 11.11 & 54.25 \\
\hline $\begin{array}{l}\text { Principal component } \\
\text { (PC) }\end{array}$ & \multicolumn{3}{|c|}{ Area $a-2012$} \\
\hline 1 & 1.71 & 18.99 & 18.99 \\
\hline 2 & 1.45 & 16.11 & 35.10 \\
\hline 3 & 1.00 & 11.11 & 46.21 \\
\hline 4 & 0.91 & 10.09 & 56.30 \\
\hline $\begin{array}{l}\text { Principal component } \\
\text { (PC) }\end{array}$ & \multicolumn{3}{|c|}{ Area $b-2000$} \\
\hline 1 & 1.62 & 17.99 & 17.99 \\
\hline 2 & 1.17 & 13.04 & 31.03 \\
\hline 3 & 1.08 & 12.03 & 43.06 \\
\hline 4 & 0.98 & 10.90 & 53.95 \\
\hline $\begin{array}{l}\text { Principal component } \\
\text { (PC) }\end{array}$ & \multicolumn{3}{|c|}{ Area $b-2012$} \\
\hline 1 & 1.62 & 18.04 & 18.04 \\
\hline 2 & 1.17 & 12.96 & 31.00 \\
\hline 3 & 1.10 & 12.18 & 43.18 \\
\hline 4 & 0.92 & 10.24 & 53.42 \\
\hline $\begin{array}{l}\text { Principal component } \\
\text { (PC) }\end{array}$ & \multicolumn{3}{|c|}{ Area $d-2000$} \\
\hline 1 & 1.80 & 17.96 & 17.96 \\
\hline 2 & 1.51 & 15.10 & 33.06 \\
\hline 3 & 1.00 & 10.00 & 43.06 \\
\hline 4 & 0.90 & 8.86 & 51.92 \\
\hline $\begin{array}{l}\text { Principal component } \\
\text { (PC) }\end{array}$ & \multicolumn{3}{|c|}{ Area $d-2012$} \\
\hline 1 & 1.66 & 16.60 & 16.60 \\
\hline 2 & 1.24 & 12.39 & 28.99 \\
\hline 3 & 1.08 & 10.75 & 39.74 \\
\hline 4 & 1.00 & 10.00 & 49.74 \\
\hline
\end{tabular}


Table 8. Results of principal component analysis (PCA) (Varimax rotated component matrix) for the areas $a, b$ and $d$, of the Brazilian Cerrado. Bolding numbers indicate the most significant variables for each principal component (PC).

\begin{tabular}{|c|c|c|c|c|}
\hline \multirow{2}{*}{ Variable } & PC 1 & PC 2 & PC 3 & PC 4 \\
\hline & \multicolumn{4}{|c|}{ Area $a-2000$} \\
\hline S-Factor & 0.039 & -0.083 & -0.004 & 0.928 \\
\hline L-Factor & -0.077 & -0.108 & 0.889 & -0.148 \\
\hline R-factor & -0.714 & 0.018 & 0.130 & -0.168 \\
\hline K-factor & 0.724 & 0.020 & 0.148 & -0.022 \\
\hline C-factor & -0.100 & 0.831 & 0.060 & 0.093 \\
\hline P-factor & 0.000 & 0.000 & 0.000 & 0.000 \\
\hline Variable & \multicolumn{4}{|c|}{ Area $a-2012$} \\
\hline S-Factor & 0.070 & 0.033 & 0.005 & 0.956 \\
\hline L-Factor & -0.108 & -0.094 & 0.899 & -0.108 \\
\hline R-factor & 0.109 & -0.709 & 0.168 & -0.142 \\
\hline K-factor & -0.103 & 0.711 & 0.180 & 0.026 \\
\hline C-factor & 0.959 & -0.094 & -0.022 & 0.065 \\
\hline P-factor & 0.000 & 0.000 & 0.000 & 0.000 \\
\hline Variable & \multicolumn{4}{|c|}{ Area $b-2000$} \\
\hline S-Factor & -0.260 & -0.106 & -0.051 & -0.725 \\
\hline L-Factor & -0.028 & -0.016 & 0.803 & 0.134 \\
\hline R-factor & -0.051 & 0.871 & -0.038 & -0.020 \\
\hline K-factor & 0.058 & 0.848 & 0.131 & -0.033 \\
\hline C-factor & 0.936 & -0.024 & 0.012 & 0.019 \\
\hline P-factor & -0.102 & 0.000 & -0.032 & -0.048 \\
\hline Variable & \multicolumn{4}{|c|}{ Area $b-2012$} \\
\hline S-Factor & -0.257 & -0.094 & -0.018 & -0.809 \\
\hline L-Factor & -0.052 & -0.022 & 0.812 & 0.118 \\
\hline R-factor & -0.116 & 0.858 & -0.032 & 0.020 \\
\hline K-factor & 0.041 & 0.858 & 0.131 & -0.037 \\
\hline C-factor & 0.937 & -0.035 & 0.023 & 0.076 \\
\hline P-factor & -0.303 & -0.041 & -0.024 & 0.068 \\
\hline Variable & \multicolumn{4}{|c|}{ Area $d-2000$} \\
\hline S-Factor & -0.002 & -0.008 & -0.131 & 0.984 \\
\hline L-Factor & -0.038 & 0.960 & 0.012 & -0.117 \\
\hline R-factor & 0.895 & 0.082 & 0.219 & -0.028 \\
\hline K-factor & 0.836 & 0.056 & -0.008 & 0.008 \\
\hline C-factor & 0.186 & 0.138 & 0.802 & -0.103 \\
\hline P-factor & -0.792 & -0.023 & -0.185 & 0.096 \\
\hline Variable & \multicolumn{4}{|c|}{ Area $d-2012$} \\
\hline S-Factor & 0.002 & 0.009 & 0.211 & 0.877 \\
\hline L-Factor & -0.041 & 0.935 & -0.099 & -0.083 \\
\hline R-factor & 0.907 & 0.108 & 0.055 & -0.082 \\
\hline K-factor & 0.763 & 0.080 & 0.249 & 0.026 \\
\hline C-factor & 0.224 & 0.106 & 0.587 & -0.583 \\
\hline P-factor & -0.894 & -0.019 & 0.098 & 0.061 \\
\hline
\end{tabular}

\subsection{Crop Productivity Loss in Severely Eroded Areas and Their Spatial Distribution}

Agricultural productivity loss occurred in 3,035,274 hectares of crop and silviculture land in 2000 and in 5,676,886 hectares in 2012 (Table 9). These areas are severely eroded $\left(>11 \mathrm{t} \mathrm{ha}^{-1} \mathrm{yr}^{-1}\right)$ and represent $13.27 \%$ (2000) and $13.80 \%$ (2012) of the total crop and silviculture area in the Cerrado. Approximately 6,689,100 tonnes of semi-perennial crops (sugarcane) are estimated to have been lost in 2000 due to severe erosion, and 16,702,100 tonnes are estimated to have been lost in 2012. Silviculture also shows a considerable loss in productivity due to severe erosion: Agricultural productivity loss occurred in 2,208,100 $\mathrm{m}^{3}$ in 2000 and in 3,108,800 $\mathrm{m}^{3}$ in 2012. Semi-perennial and silviculture were the 
land use types that lost most soil in both 2000 and 2012 (Table 6). The lowest productivity loss (as a percentage) is found in annual crops (soy and maize) due to their having the lowest erosion rates.

The potential impact of agricultural productivity loss due to severe erosion on food security is difficult to quantify, especially at a regional scale, given that it involves different factors such as food price and distribution and consumer income [99]. However, the significant increase of the agricultural productivity loss in crops and silviculture-from 9,204,000 tonnes in 2000 to 20,289,000 tonnes in 2012-indicates that government policy should be directed to ensure the sustainable use of soils, including appropriate crop and soil management practices to maintain soil quality and crop productivity. Despite the importance of soil conservation, the implementation of practices to minimize soil erosion has not followed apace with the severity of the problem [100].

Table 9. Estimated productivity loss for crops and silviculture in the Brazilian Cerrado in 2000 and 2012.

\begin{tabular}{|c|c|c|c|c|c|}
\hline \multirow[t]{2}{*}{ Land Use } & $\begin{array}{l}\text { Total Area } \\
\text { (1000 ha) }\end{array}$ & $\begin{array}{c}\text { Productivity } \\
\left(1000 \mathrm{t}^{*} \text { or } \mathrm{m}^{3 * *}\right)\end{array}$ & $\begin{array}{l}\text { Area Severely } \\
\text { Eroded (1000 ha) }\end{array}$ & $\begin{array}{l}\text { Crop Productivity } \\
\text { Loss in Severely } \\
\text { Eroded Areas (1000 t) }\end{array}$ & $\begin{array}{c}\% \text { of Crop Loss } \\
\left(t^{*} \text { or } \mathrm{m}^{3 * *}\right)\end{array}$ \\
\hline & \multicolumn{5}{|c|}{2000} \\
\hline Annual (soy) & 3715 & 9758 & 561 & 103 & 1.06 \\
\hline Annual (maize) & 3431 & 12,966 & 518 & 151 & 1.16 \\
\hline Semi-perennial & 1824 & 149,890 & 1018 & 6689 & 4.46 \\
\hline Perennial & 653 & 1588 & 277 & 53 & 3.33 \\
\hline Silviculture & 1654 & 67,820 & 662 & 2208 & 3.26 \\
\hline Land use & \multicolumn{5}{|c|}{2012} \\
\hline Annual (soy) & 7874 & 25,601 & 1319 & 325 & 1.27 \\
\hline Annual (maize) & 4725 & 32,188 & 791 & 418 & 1.30 \\
\hline Semi-perennial & 4258 & 378,993 & 2354 & 16,702 & 4.41 \\
\hline Perennial & 960 & 1782 & 411 & 60 & 3.35 \\
\hline Silviculture & 1880 & 89,333 & 803 & 3109 & 3.48 \\
\hline
\end{tabular}

Figure 5 shows the areas which are severely eroded in the Brazilian Cerrado, including pasture. These areas are especially located in consolidated agricultural regions. The states of Goiás, Mato Grosso do Sul, and Minas Gerais show areas of severe erosion in pasture lands. São Paulo state contains concentrated areas where severe erosion is caused mainly by semi-perennial crops (sugarcane). In the south of São Paulo, Paraná, and Mato Grosso states are areas with a predominance of annual crop erosion. Areas which are severely eroded by silviculture can be seen in the Paraná, Minas Gerais, and Mato Grosso do Sul states. These areas, shown in Figure 5, show a decrease in agricultural productivity (Table 9) and nutrients (as shown in the next section), and can be considered as priority areas for soil conservation. Productivity loss in pasture lands was not measured due to a lack of data for grass production. The natural vegetation class was included in Figure 5, however the severe erosion of natural vegetation areas is due to natural processes of erosion resulting from very steep slopes and sparse vegetation.

The loss of crop productivity due to severe erosion causes economic loss [8]. In the European Union (EU), the total economic loss in agricultural productivity due to severe erosion is around 1.257 billion EUR (reference year: 2010), which corresponds to $0.43 \%$ of the EU's total agriculture sector contribution to Gross Domestic Product (estimated at 292.320 billion EUR) [8]. In the case of Brazil, there is no available estimate for the total economic loss caused by agricultural productivity loss. However, some studies point out that the economic costs caused by water erosion can reach 242 million USD a year for some Brazilian states [101]. According to our study, Brazilian states located in agricultural consolidated regions of the Cerrado will experience higher economic losses due to extensive areas of severe erosion (Figure 5). 


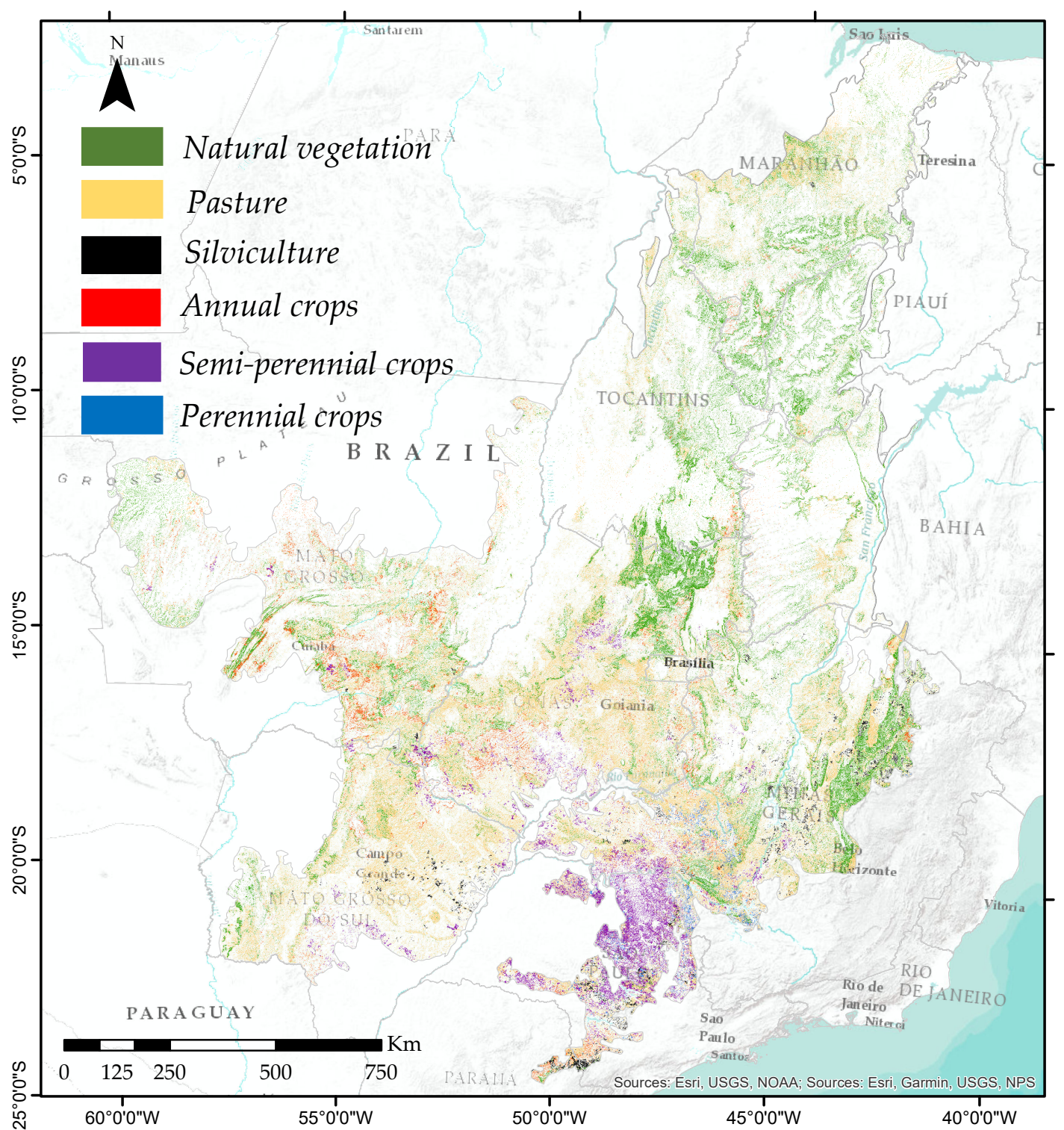

Figure 5. Severely eroded ( $\left.>11 \mathrm{t} \mathrm{ha}^{-1} \mathrm{yr}^{-1}\right)$ areas in the Brazilian Cerrado (reference year: 2012).

\subsection{Potential Nutrient Loss in Severely Eroded Lands}

Considering that nutrient loss is one of the factors that contributes to the decrease of agricultural productivity, Table 10 presents the general average rate of nutrient loss for each land use cover. Moreover, Table 10 specifies the average rate of nutrient loss in areas with different soil loss for the years 2000 and 2012: low and moderate soil loss areas $\left(\leq 11 \mathrm{tha}^{-1} \mathrm{yr}^{-1}\right)$ and severely eroded areas $\left(>11 \mathrm{t} \mathrm{ha}^{-1} \mathrm{yr}^{-1}\right)$. In general, nutrient loss by water erosion increased between 2000 and 2012 in the Cerrado. Severely eroded areas lost 13.2 to 25.9 times more nitrogen and 13.1 to 23.1 times more phosphorus than areas with low and moderate soil loss rates. This means that the quantity of nutrients lost in severely eroded areas are not well replenished by fertilizers, resulting in soil nutrient deficit. These lands require more agricultural inputs, have higher production costs, and require the application of techniques for drainage and erosion control [4]. Considering that Cerrado soils are naturally nutrient-poor for agricultural production, this study shows that high and severe erosion are making Cerrado soils increasingly nutrient poor. 
Table 10. Simulated potential nutrient loss rates $\left(\mathrm{kg} \mathrm{ha}^{-1}\right.$ for $\mathrm{N}$ and $\mathrm{g} \mathrm{ha}{ }^{-1}$ for $\left.\mathrm{P}\right)$ for agricultural lands of the Brazilian Cerrado for the years 2000 and 2012.

\begin{tabular}{|c|c|c|c|c|c|c|}
\hline \multirow[t]{2}{*}{ Land Use Cover } & \multicolumn{2}{|c|}{ Average Soil Nutrient Loss } & \multicolumn{2}{|c|}{$\begin{array}{c}\text { Average Soil Nutrient Loss in } \\
\text { Moderately Eroded Areas } \\
\left(\leq 11 \mathrm{tha}^{-1} \mathrm{yr}^{-1}\right)\end{array}$} & \multicolumn{2}{|c|}{$\begin{array}{c}\text { Average Soil Nutrient Loss in } \\
\text { Severely Eroded Areas (>11 t } \\
\left.\qquad \mathrm{ha}^{-1} \mathrm{yr}^{-1}\right)\end{array}$} \\
\hline & 2000 & 2012 & 2000 & 2012 & 2000 & 2012 \\
\hline & \multicolumn{6}{|c|}{ Nitrogen $\left(\mathrm{kg} \mathrm{ha}^{-1}\right)$} \\
\hline Pasture & 14.3 & 14.8 & 3.1 & 3.1 & 50.3 & 50.9 \\
\hline Silviculture & 33.2 & 40.3 & 3.7 & 4.0 & 76.6 & 88.1 \\
\hline Annual & 13.5 & 12.0 & 2.9 & 2.9 & 72.6 & 57.0 \\
\hline Semi Perennial & 46.7 & 48.0 & 6.0 & 5.9 & 78.0 & 81.2 \\
\hline \multirow[t]{2}{*}{ Perennial } & 34.3 & 35.6 & 4.7 & 4.6 & 73.8 & 76.2 \\
\hline & \multicolumn{6}{|c|}{ Phosphorus $\left(\mathrm{g} \mathrm{ha}^{-1}\right)$} \\
\hline Pasture & 5.1 & 5.4 & 1.1 & 1.1 & 18.0 & 18.4 \\
\hline Silviculture & 13.7 & 16.3 & 1.5 & 1.6 & 31.8 & 35.8 \\
\hline Annual & 3.9 & 4.1 & 0.9 & 0.9 & 20.8 & 19.9 \\
\hline Semi Perennial & 14.1 & 14.8 & 1.8 & 1.8 & 23.5 & 25.0 \\
\hline Perennial & 11.4 & 12.7 & 1.4 & 1.4 & 24.7 & 27.4 \\
\hline
\end{tabular}

The amount of nutrient loss caused by erosion depends on both the nutrient concentration of eroded soil and the total amount of soil loss [102-105]. As expected, the average rate of nutrient loss was higher in semi-perennial crops, silviculture, and perennial crops, as these have the highest soil loss rates. Those crops use conventional tillage, which studies point out can result in up to nine times more nutrient loss than those areas that use conservationist practices which combine the effect of increased soil plant residues and, consequently, lead to the reduction of soil and water losses [105]. With agricultural expansion between 2000 and 2012, the average rate of soil nitrogen loss increased by $21.4 \%$ in silviculture, $2.8 \%$ in semi-perennial crops, and $3.8 \%$ in perennial crops (Table 10 ). The average rate of soil phosphorus loss increased by $19.0 \%$ in silviculture, $5.0 \%$ in semi-perennial crops, and $3.2 \%$ in perennial crops. As annual crops and pasture have the lowest soil loss rates, the average rate of nutrient loss is also lower for these land use types. Additionally, conservationist practices applied in annual crops favor lower nutrient losses. Between 2000 and 2012 the average nitrogen loss rate reduced by $11.1 \%$ for annual crops and increased by $3.5 \%$ for pasture. In the case of phosphorus, the average loss rate increased by $5.1 \%$ and $5.9 \%$ for annual crops and pasture, respectively.

Although the addition of fertilizer alone cannot compensate for all the nutrients lost when the thin topsoil layer is eroded [4], further expenditure with fertilizers is required to improve productivity [100]. The costs of energy to produce nitrogen fertilizer and phosphorus shortage have caused concern about the availability of inorganic fertilizers for farmers in developing countries, given the increased price of these nutrients [100]. As a solution, more efficient nutrient recycling and improved agricultural soil practices are needed, as discussed in Section 4.4. Figure 6 shows the map of potential nitrogen and phosphorus loss rate for the Brazilian Cerrado. 


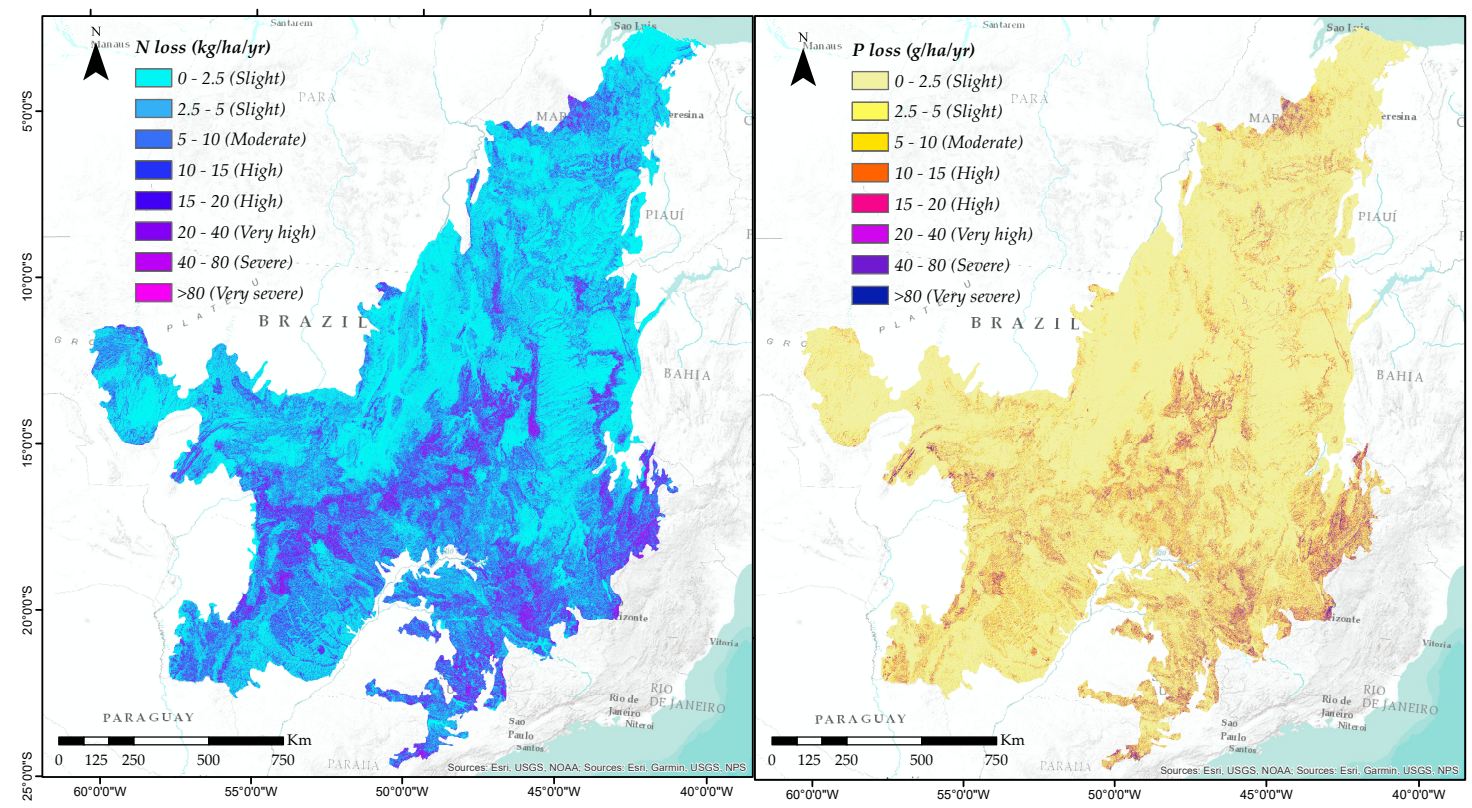

Figure 6. Map of potential nitrogen $\left(\mathrm{kg} \mathrm{N} \mathrm{ha}^{-1} \mathrm{yr}^{-1}\right)$ and phosphorus $\left(\mathrm{gP} \mathrm{ha}^{-1} \mathrm{yr}^{-1}\right)$ loss rate for the Brazilian Cerrado (Reference year: 2012).

\subsection{Priority Areas for Soil Conservation and Erosion Control Practices}

In the 21st century, soil degradation is considered to be a global problem, most critically in the tropics. Soil degradation accounted for a decrease in soil ecosystem services by $60 \%$ between 1950 and 2010 [106]. Furthermore, soil degradation can also dampen economic growth, especially in countries where agriculture is the engine for economic development [107].

In all severely eroded areas of the Cerrado, conservation practices must be applied to improve soil conditions and boost productivity. Minimal soil disturbance, zero tillage, permanent soil cover, and crop rotations are some conservation principles that can be applied in severely eroded agricultural lands. Figure 5 shows the severely eroded areas which are a priority for soil conservation. As mentioned before, the agricultural consolidated region is the most affected by severe erosion. Although there is a tendency of crops expanded over pasture lands in the Cerrado, there are still large degraded areas of pasture under intensive erosive processes that need to be rehabilitated [38,77]. Semi-perennial crops lead to strong erosive processes on soil, mainly in the south of the Cerrado. In these plantations, crop residues could be kept on the soils to protect them. Additionally, at the end of the sugarcane cycle, soil exposition could be avoided by planting other crops [108]. Silviculture and perennial crops were previously planted in areas with slope above $12 \%$, occasioning strong erosion; those areas could be avoided due to the impact of mechanization disturbances and disturbances on drainage lines. Conventional tillage in annual crop lands should be replaced by reduced tillage, or tillage should be stopped, to decrease erosion.

According to [109], practices of conservation agriculture that could help to avoid soil degradation and erosion include the retention of crop residue, the incorporation of cover crops in the rotation cycle, the use of integrated nutrient management (INM) involving a combination of chemical and biological fertilizers, and the elimination of soil mechanical disturbances. Additionally, the use of organic amendments rich in nutrients (such as nitrogen), by recycling organic by-products including urban waste, is a useful strategy to enhance soil fertility and improve structural stability or aggregates that could be an alternative to soil conservation [109]. Furthermore, in order to strengthen soil conservation, strong government programs are necessary, not only from state programs, but also from Federal Government programs to provide the diffusion of conservation practices and technical and financial conditions to recover degraded areas. Brazil has good soil conservation practices, such 
as crop-livestock-forest integration (ILPF, in Portuguese), but these need to be further disseminated among farmers, and financial incentives for farmers would be welcome to make such practice a reality.

\subsection{Limitations of This Study}

The main limitations that should be considered in this study are: (a) the soil erosion estimates as outputs of the RUSLE model; (b) the erosivity data; (c) the estimates of productivity loss; and (d) the estimates of nutrient loss in agricultural lands.

The first limitation is the application of RUSLE and the prediction of potential soil loss rates. The calculation of erosion rates for about 2 million $\mathrm{km}^{2}$ is a very large challenge. Indeed, that is the main reason for using models to estimate erosion rates. The estimation of erosion rates based on empirical data is more appropriate for small catchments. There are some plot studies of soil erosion $[108,110]$, however these are not perfectly suited for model validation as they are not compatible with the model outputs. According to [30], soil erosion models should incorporate and be validated by field-based assessments of erosion. However, plot data must be collected in a way that is suitable for comparison with model outputs, which in general express erosion rates in terms of physical quantities. An advantage of this study is that the RUSLE model was applied at 94-m resolution, which is suitable for use in large areas such as the Cerrado.

The second limitation is concerned with the erosivity data. Ideally, different temporal series of precipitation data should be used to calculate erosivity for the years 2000 and 2012 in order to better represent the precipitation variability over the 12-year period. However, due to a lack of erosivity data for different temporal series, we used the same erosivity data [54] for both periods (2000 and 2012). Considering that the sensibility of the RUSLE model is only about $12 \%$ for the erosivity factor for water erosion in Brazil, and about 66\% for the cover management factor [111], we believe that the application of both land use and cover maps for the years 2000 and 2012 allowed the RUSLE model to adequately represent the soil loss that occurred in this period in the Brazilian Cerrado.

The third limitation is the estimation of agricultural productivity loss. Based on [8], we assumed that a crop productivity loss of $8 \%$ occurs in intensively cultivated agricultural lands. However, this percentage can vary according to the soil and crop type.

The last limitation, but not the least important, concerns the estimates of the loss of nutrients. We recognized that there are significant variations in the quantity of nutrients in the soil even when the soils are of the same type. However, there is a limitation in that this study did not georeference available plots of nutrients loss in the Cerrado. This limitation resulted in a homogeneous distribution of nitrogen and phosphorus amounts across the same soil type, which we consider as suitable for a study area of about 2 million $\mathrm{km}^{2}$. Another point to note is that our estimates may underestimate nutrient loss by erosion because we did not consider the nutrient input from fertilizers.

\section{Conclusions}

The management of soil quality is essential to provide food to people, as well as to strengthen and sustain ecosystem services. The soil is non-renewable over human timescale (decades), and conservation practices are central to guarantee goods for future generations. Recognizing that, this study addresses the challenge of food security, soil degradation, and the importance of the Brazilian Cerrado for meeting future agricultural production. This is the first study that combines estimates of the potential soil loss, potential agricultural productivity loss, and potential soil nutrient loss for agricultural lands on the scale of the Brazilian Cerrado for the years 2000 and 2012. The main findings indicate that: (1) the average soil loss rate in the Brazilian Cerrado increased from $10.4 \mathrm{t} \mathrm{ha}^{-1} \mathrm{yr}^{-1}$ (2000) to $12.0 \mathrm{t} \mathrm{ha}^{-1} \mathrm{yr}^{-1}$ (2012) as a result of agricultural expansion. Semi-perennial crops, silviculture, and perennial crops have the highest rates of soil loss; (2) agricultural productivity loss associated with severely eroded soil increased significantly, from 3 million hectares of crops and silviculture in 2000 to 5.5 million hectares in 2012. These areas represent $13.3 \%$ (2000) and 13.8\% (2012) of the total crop and silviculture area in the Cerrado; (3) severely eroded areas lost between 13.2 and 25.9 times more 
nitrogen and between 13.1 and 23.1 times more phosphorus than areas with low and moderate soil loss rates; (4) government policy should be directed to ensure the sustainable use of soil, mainly in agriculturally consolidated regions of the Brazilian Cerrado, where severely eroded areas are increasing, leading to a decrease in agricultural productivity and the depletion of soil nutrients. Brazilian states located in agricultural consolidated regions may experience considerable negative economic effects as a result of extensive areas of severe erosion; (5) in this sense, soil erodibility (K-factor), cover management ( $\mathrm{C}$-factor) and erosivity (R-factor) are relevant factors that contribute most with erosion processes in three agriculturally consolidated areas selected within the Brazilian Cerrado. This finding suggests that agricultural management practices could be differentiated and applied according to the regional characteristics.

Although the estimations above presented an increase in soil erosion and consequential loss of soil productivity and nutrients over time in the Cerrado, some limitations need to be taken into account in future evaluations. The estimation of erosion rates by models such as RUSLE for large areas may lead to uncertainties and resolution is central to lead to more accurate outputs. Moreover, soil erosion models should incorporate and be validated by field-based assessments of erosion if available. Furthermore, the lack of some important data such as erosivity for different time series, punctual estimation of productivity and nutrient loss limit the accuracy of the model and may affect the sensitivity analysis of the model output.

Author Contributions: L.G., S.J.C.S., J.P.H.B.O., M.C.F., and E.L.D.N. designed the study with input from all authors. Data analysis was performed by L.G. with contributions from all authors. L.G. and S.J.C.S. prepared the figures. The paper was written by L.G., S.J.C.S., and E.R.d.S.-N. All authors read, commented on, and approved the final version of the manuscript.

Funding: This research was funded by CAPES (Coordination for the Improvement for the Higher Education Personnel) by L.G.'s scholarship number 1476816, and Natural Environmental Research Council (NERC) by the project "Sustainable Gas Pathways for Brazil; from Microcosm to Macrocosm (NE/N018656/1)". This research was also funded by projects "Nitrogen Cycling in Latin America: Drivers, Impacts, and Vulnerabilities (CRN3005)", "FAPESP-Belmont Forum, DEVIL-Promoting food security with restricted land availability (2014/50627-2)", and "Forests 2020 - part of the UK Space Agency's International Partnership Programme (IPP), funded by the UK's Global Challenges Research Fund (GCRF)".

Acknowledgments: The authors would like to thank the Earth System Science Center (CCST), National Institute for Space Research (INPE), for the graduate opportunity, and the School of Geography, University of Leeds, for the support and infrastructure. We are also grateful to the reviewers for their excellent contributions and to Grasiela Medeiros, Maria Isabel Sobral Escada, and Márcio de Morrison Valeriano for their initial suggestions for this research.

Conflicts of Interest: The authors declare no conflict of interest.

\section{References}

1. Godfray, H.C.J.; Beddington, J.R.; Crute, I.R.; Haddad, L.; Lawrence, D.; Muir, J.F.; Pretty, J.; Robinson, S.; Thomas, S.M.; Toulmin, C. Food Security: The Challenge of Feeding 9 Billion People. Science 2010, 327, 812-818. [CrossRef] [PubMed]

2. Rojas, R.V.; Achouri, M.; Maroullins, J.; Caon, L. Healthy soils: A prerequisite for sustainable food security. Environ. Earth Sci. 2016, 75, 180. [CrossRef]

3. Montanarella, L.; Pennock, D.J.; McKenzie, N.; Badraoui, M.; Chude, V.; Baptista, I.; Mamo, T.; Yemefack, M.; Aulakh, M.S.; Yagi, K.; et al. World's soils are under threat. Soil 2016, 2, 79-82. [CrossRef]

4. FAO and ITPS. Status of the World's Soil Resources (SWSR)_Main Report; Food and Agriculture Organization of the United Nations and Intergovernmental Technical Panel on Soils: Rome, Italy, 2015.

5. Berhe, A.A.; Torn, M.S. Erosion redistribution of topsoil controls soil nitrogen dynamics. Biogeochemistry 2017, 132, 37-54. [CrossRef]

6. Berhe, A.A.; Barnes, R.T.; Six, J.; Marin-Spiotta, E. Role of soil erosion in biogeochemical cycling of essential elements: Carbon, nitrogen, and phosphorus. Ann. Rev. Earth Planet. Sci. 2018, 46, 521-548. [CrossRef]

7. Berhe, A.A.; Arnold, C.; Stacy, E.; Lever, R.; McCorkle, E.; Araya, S.N. Soil erosion controls on biogeochemical cycling of carbon and nitrogen. Nat. Educ. Knowl. 2014, 5, 2. 
8. Panagos, P.; Standardi, G.; Borrelli, P.; Lugato, E.; Montanarella, E.; Bosello, F. Cost of agricultural productivity loss due to soil erosion in the European Union: From direct cost evaluation approaches to the use of macroeconomic models. Land Degrad. Dev. 2018, 29, 471-484. [CrossRef]

9. Pimentel, D.; Kounang, N. Ecology of soil erosion in ecosystems. Ecosystems 1998, 1, 416-426. [CrossRef]

10. Lal, R. Soil erosion in the humid tropics with particular reference to agricultural land development and soil management. In Hydrology of Humid Tropical Regions with Particular Reference to the Hydrological Effects of Agriculture and Forestry Practice (Proceedings of the Hamburg Symposium), IAHS'Publ. no. 140; IAHS: Wallingford, UK, 1983.

11. Stocking, M.A. Tropical soils and food security. Science 2003, 302, 1356-1359. [CrossRef]

12. Alexandratos, N.; Bruinsma, J. World Agriculture towards 2030/2050: The 2012 Revision; ESA Working paper No. 12-03; FAO: Rome, Italy, 2012.

13. Tilman, D.; Balzer, C.; Hill, J.; Belfort, B.L. Global food demand and the sustainable intensification of agriculture. Proc. Natl. Acad. Sci. USA 2011, 108, 20260-20264. [CrossRef]

14. Lambin, E.F.; Mwyfroidt, P. Global land use change, economic globalization, and the looming land scarcity. Proc. Natl. Acad. Sci. USA 2011, 108, 3465-3472. [CrossRef] [PubMed]

15. OECD/Food and Agriculture Organization of the United Nations. OECD-FAO Agricultural Outlook 2015; OECD Publishing: Paris, France, 2015.

16. Rada, N. Assessing Brazil's Cerrado Agricultural Miracle. Food Policy 2013, 28, 146-155. [CrossRef]

17. Wickramasinghe, U.; Syed, S.; Siregar, H. The Role of Policies in Agricultural Transformation. Lessons from Brazil, Indonesia and the Republic of Korea; CAPSA Working Paper No. 106; CAPSA: Indonesia, 2012.

18. Brazilian Institute of Geography and Statistics (IBGE). Produção Agrícola Municipal; Sistema IBGE de Recuperação Automática-SIDRA: Rio de Janeiro, Brazil, 2000; (In Portuguese). Available online: https: / / sidra.ibge.gov.br/tabela/1612 (accessed on 5 October 2015).

19. Leite, R.C.C.; Leal, M.R.L.V.; Cortez, L.A.B.; Griffin, W.M.; Scandiffio, M.I.G. Can Brazil replace 5\% of the 2025 gasoline world demand with ethanol? Energy 2009, 34, 655-661. [CrossRef]

20. Balcombe, K.; Rapsomanikis, G. Bayesian estimation and selection of nonlinear vector error correction models: The case of the sugar-ethanol-oil nexus in Brazil. Am. J. Agric. Econ. 2008, 90, 658-668. [CrossRef]

21. Scherr, S.J.; Yadav, S. Land Degradation in the Developing World: Implications for Food, Agriculture, and the Environment to 2020; Food, Agriculture, and the Environment Discussion Paper 14; FAO: Rome, Italy, 1996.

22. Solaimani, K.; Modallaldoust, S.; Lotfi, S. Investigation of land use changes on soil erosion processes using geographical information system. Int. J. Environ. Sci. Technol 2009, 6, 415-424. [CrossRef]

23. Brath, A.; Castellarin, A.; Montanari, A. Evaluating the effects of land use changes on annual average gross erosion. Hydrol. Earth Syst. Sci. 2002, 6, 255-265. [CrossRef]

24. Panagos, P.; Borrelli, P.; Poesen, J.; Ballabio, C.; Lugato, E.; Meusburger, K.; Montanarella, L.; Alewell, C. The new assessment of soil loss by water erosion in Europe. Environ. Sci. Policy 2015, 54, 438-447. [CrossRef]

25. Wischmeier, W.H.; Smith, D.D. Predicting Rainfall Erosion Losses: A Guide to Conservation Planning; Agriculture Handbook No. 537; U.S. Department of Agriculture (USDA): Washington, DC, USA, 1978.

26. Renard, K.G.; Foster, G.R.; Weesies, G.A.; McCool, D.K.; Yoder, D.C. Predicting Soil Erosion by Water: A Guide to Conservation Planning with the Revised Universal Soil Loss Equation (RUSLE); Agriculture Handbook No. 703; U.S. Department of Agriculture (USDA): Washington, DC, USA, 1997.

27. Zhang, H.; Yang, Q.; Li, R.; Liu, Q.; Moore, D.; He, P.; Ritsema, C.J.; Geissen, V. Extension of a GIS procedure for calculating the RUSLE equation LS factor. Comput. Geosci. 2013, 52, 177-188. [CrossRef]

28. Liu, J.; You, L.; Amini, M.; Obersteiner, M.; Herrero, M.; Zehnder, A.J.B.; Yang, H. A high-resolution assessment on global nitrogen flows in cropland. Proc. Natl. Acad. Sci. USA 2010, 107, 8035-8040. [CrossRef]

29. Smaling, E.M.A.; Roscoe, R.; Lesschen, J.P.; Bouwman, A.F.; Comunello, E. From forest to waste: Assessment of the Brazilian soybean chain, using nitrogen as a marker. Agri. Ecosyst. Environ. 2008, 128, 185-197. [CrossRef]

30. Panagos, P.; Borrelli, P.; Poesen, J.; Ballabio, C.; Lugato, E.; Meusburger, K.; Montanarella, L.; Alewell, C. Reply to "The new assessment of soil loss by water erosion in Europe. Panagos, P. et al., 2015 Environ. Sci. Policy 54, 438-447-A response" by Evans and Boardman [Environ. Sci. Policy 58, 11-15]. Environ. Sci. Policy 2016, 59, 143-150. [CrossRef]

31. Oreskes, N.; Shrader-Frechette, K.; Belitz, K. Verification, validation, and confirmation of numerical models in the earth sciences. Science 1994, 263, 641-646. [CrossRef] 
32. Galdino, S.; Sano, E.E.; Andrade, R.G.; Grego, C.R.; Nogueira, S.F.; Bragantini, C.; Flosi, A.H.G. Large-scale modeling of soil erosion with RUSLE for conservation planning of degraded cultivated Brazilian pastures. Land Degrad. Dev. 2015, 27, 773-784. [CrossRef]

33. Cunha, E.R.; Bacani, V.M.; Panachuki, E. Modeling soil erosion RUSLE and GIS in a watershed occupied by rural settlement in the Brazilian Cerrado. Nat. Hazards 2016, 85, 851-868. [CrossRef]

34. Amorim, R.S.S.; da Silva, D.; Pruski, F.F.; Matos, A.T. Avaliação do desempenho dos modelos de predição da erosão hídrica USLE, RUSLE e WEPP para diferentes condições edafoclimáticas do Brasil. Eng. Agríc. 2010, 30, 1046-1049. (In Portuguese) [CrossRef]

35. Bramorski, J.; Trivelin, P.C.O.; Crestana, S. Nitrogen loss by erosion from mechanically tilled and untilled soil under successive simulated rainfalls. Rev. Bras. Cienc. Solo 2015, 39, 1204-1211. [CrossRef]

36. Oliveira, P.T.S. Water Balance and Soil Erosion in the Brazilian Cerrado. Ph.D. Thesis, Science-Hydraulics and Sanitary Engineering, University of São Paulo, São Carlos, Bazil, 2014.

37. Anache, J.A.A.; Wendland, E.C.; Oliveira, P.T.S.; Flanagan, D.S.; Nearing, N.A. Runoff and soil erosion plot-scale studies under natural rainfall: A meta-analysis of the Brazilian experience. Catena 2017, 152, $29-39$. [CrossRef]

38. Peron, A.J.; Evangelista, A.R. Degradação de pastagens em regiões de Cerrado. Ciênc. Agrotec. 2004, 28, 655-661. (In Portuguese) [CrossRef]

39. Sano, S.M.; Almeida, S.P.; Ribeiro, J.F. Cerrado: Ecologia e Flora; Embrapa Informacão Tecnológica, Embrapa Cerrados: Brasília, Brazil, 2008. (In Portuguese)

40. Lewinsohn, T.M.; Prado, P.I. How Many Species Are There in Brazil? Cuantas Especies Hay en Brasil? Conserv. Biol. 2005, 19, 619-624. [CrossRef]

41. Myers, N.; Mittermeier, R.A.; Mittermeier, C.G.; Fonseca, G.A.B.; Kent, J. Biodiversity hotspots for conservation priorities. Nature 2000, 403, 853-858. [CrossRef] [PubMed]

42. Bustamante, M.M.C.; Nardoto, G.B.; Pinto, A.S.; Resende, J.C.F.; Takahashi, F.S.C.; Vieira, L.C.G. Potential Impacts of Climate Change on Biogeochemical Functioning of Cerrado Ecosystems. Braz. J. Biol. 2012, 72, 655-671. [CrossRef] [PubMed]

43. Eiten, G. The cerrado vegetation of Brazil. Botan. Rev. 1972, 38, 201-341. [CrossRef]

44. Cochrane, T.T.; Jones, P.G. Savannas, forests and wet season potential evapotranspiration in tropical South America. Trop. Agric. 1981, 58, 85-190.

45. Oliveira-Filho, A.; Ratter, J. Vegetation physiognomies and woody flora of the Cerrado biome. In The Cerrado of Brazil. Ecology and Natural History of a Neotropical Savanna; Oliviera, P.S., Marquis, T.J., Eds.; Columbia University Press: New York, NY, USA, 2002; pp. 91-120.

46. Santos, H.G.; Carvalho Junior, W.; Dart, R.O.; Áglio, M.L.D.; Sousa, J.S.; Pares, J.G.; Fontana, A.; Martins, A.L.S.; Oliveira, A.P. O Novo Mapas de Solos do Brasil. Legenda Atualizada—Dados Eletrônicos; Embrapa Solos: Rio de Janeiro, Brazil, 2011; 67p. (In Portuguese)

47. Medina, E. Mineral Nutrition: Tropical Savannas. Prog. Bot. 1993, 54, 237-253.

48. Valeriano, M.M.; Rosseti, D.F.; Albuquerque, P.C.G. Topodata: Desenvolvimento da primeira versão do banco de dados geomorfométricos locais em cobertura nacional. In Proceedings of the Simpósio Brasileiro de Sensoriamento Remoto, Natal, Brazil, 25-30 April 2009; INPE: São José dos Campos, Bazil, 2009; pp. 5499-5506. (In Portuguese). Available online: http://urlib.net/dpi.inpe.br/sbsr@80/2008/11.14.21.06 (accessed on 5 October 2015).

49. Ferreira, M.E.; Ferreira, L.G.; Miziara, F.; Soares-Filho, B.S. Modeling landscape dynamics in the central Brazilian savanna biome: Future scenarios and perspectives for conservation. J. Land Use Sci. 2013, 8, 403-421. [CrossRef]

50. Brazilian Ministry of the Environment (MMA). Mapeamento do uso e Cobertura da Terra do Cerrado: Projeto TerraClass Cerrado 2013; Ministério do Meio Ambiente, coordenação da Casa Civil da Presidência da República (MMA): Brasília, Brazil, 2015; 69p. (In Portuguese)

51. Brazilian Food Supply Company (CONAB). Séries Históricas de Área Plantada, Produtividade e Produção Relativas às Safras 1976/77 a 2015/2016 de Grãos; CONAB: Brasília, Brazil, 2016. (In Portuguese)

52. Lahsen, M.; Bustamante, M.M.C.; Dalla-Nora, E.L. Undervaluing and Overexploiting the Brazilian Cerrado at Our Peril. Environ. Sci. Policy Sustain. Dev. 2016, 58, 4-15. [CrossRef]

53. Brazilian Food Supply Company (CONAB). Acompanhamento da Safra Brasileira: Grãos—Safra 2010/2011; Companhia Nacional de Abastecimento: Brasília, Brazil, 2011. (In Portuguese) 
54. Oliveira, P.T.S.; Wendland, E.; Nearing, M.A. Rainfall erosivity in Brazil: A review. Catena 2012, 100, $139-147$. [CrossRef]

55. Brazilian Institute of Geography and Statistics (IBGE). Mudança na Cobertura e uso da Terra 2000-2010-2012-2014; IBGE: Rio de Janeiro, Brazil, 2015. (In Portuguese)

56. Brazilian Food Supply Company (CONAB). Séries Históricas de Área Plantada Relativas às Safras 2000/2001 de Grãos; CONAB: Brasília, Brazil, 2015.

57. Brazilian Food Supply Company (CONAB). Séries Históricas de Área Plantada Relativas às Safras 2011/2012 de Grãos; CONAB: Brasília, Brazil, 2015. (In Portuguese)

58. Rudorff, B.F.T.; Aguiar, D.A.; Silva, W.F.; Sugawara, L.M.; Adami, M.; Moreira, M.A. Studies on the Rapid Expansion of Sugarcane for Ethanol Production in São Paulo State (Brazil) Using Landsat Data. Remote Sens. 2010, 2, 1057-1076. [CrossRef]

59. Moreira, M.A.; Rudorff, B.F.T.; Barros, M.A.; de Faria, V.G.C.; Adami, M.A. Geotecnologias para mapear lavouras de café nos Estados de Minas Gerais e São Paulo. Eng. Agr. Jaboticabal 2010, 30, 1123-1135. [CrossRef]

60. Zhang, L.; O'Neill, A.; Lacy, S. Spatial Analysis of Soil Erosion in Catchments: A Review of modeling Approaches. Water Res. Ecol. 1995, 3, 58-64.

61. Kinnel, P.I.A. Event Soil Loss, Runoff and the Universal Soil Loss Equation family of models: A Review. J. Hidrol. 2010, 385, 384-397. [CrossRef]

62. Wischmeier, W.H.; Mannering, J.V. Soil and Water Management and Conservation. Relation of Soil Properties to its Erodibility. Soil Sci. Soc. Am. Proc. 1969, 33, 131-137. [CrossRef]

63. Farhan, Y.; Nawaiseh, S. Spatial assessment of soil erosion risk using RUSLE and GIS techniques. Environ. Earth Sci. 2015, 74, 4649-4669. [CrossRef]

64. Farinasso, M.; Carvalho Júnior, O.A.; Guimarães, R.F.; Gomes, R.A.T.; Ramos, V.M. Avaliação Quantitativa do Potencial de Erosão Laminar em Grandes Áreas por meio de EUPS—Equação Universal de Perdas de Solos Utilizando Novas Metodologias em SIG para os Cálculos dos seus Fatores na Região do Alto Parnaíba-PI-MA. Rev. Bras. Morfol. 2006, 7, 73-85. (In Portuguese)

65. Castro, W.J.; Lemke-de-Castro, M.L.; Lima, J.O.; Oliveira, L.F.C.; Rodrigues, C.; Figueiredo, C.C. Erodibilidade de Solos do Cerrado Goiano. Revista em Agronegócios e Meio Ambiente 2011, 4, 305-320. (In Portuguese)

66. Mannigel, A.R.; Carvalho, M.P.; Moreti, D.; Luciano, R.M. Fator Erodibilidade e Tolerância de Perda de Solos do Estado de São Paulo. Acta Scientiarum 2002, 24, 1335-1340. [CrossRef]

67. da Silva, A.M.; Silva, M.L.N.; Curi, N.; Avanzi, J.C.; Ferreira, M.M. Erosividade da Chuva e Erodibilidade de Cambissolo e Latossolo na Região de Lavras, Sul de Minas Gerais. Rev. Bras. Cienc. Solo 2009, 33, 1811-1820. (In Portuguese) [CrossRef]

68. Cabral, J.B.P.; Becegato, V.A.; Scopel, I.; Lopes, R.M. Uso de Técnicas de Geoprocessamento para Mapear o Potencial Natural de Erosão da Chuva na Bacia Hidrográfica do Reservatório de Cachoeira Dourada-GO/MG. Revista Ra'E Ga 2005, 10, 107-116. (In Portuguese) [CrossRef]

69. Demarchi, J.C.; Zimback, C.R.L. Mapeamento, Erodibilidade e Tolerância de Perda de Solo na Sub-bacia do Ribeirão das Perobas. Energia na Agricultura 2014, 29, 102-114. (In Portuguese) [CrossRef]

70. da Silva, A.M.; Alvares, C.A. Levantamento de Informações e Estruturação de um Banco de Dados sobre a Erodibilidade de Classes de Solos no Estado de São Paulo. Geociências 2005, 24, 33-41. (In Portuguese)

71. Ahmad, N.; Mermut, A. Vertisols and Technologies for Their Management; Elsevier: Amsterdam, The Netherlands, 2003; p. 152.

72. Brooks, K.N.; Folliott, P.F.; Gregersen, H.M.; Deabano, L.F. Hydrology and the Management of Watershed, 4th ed.; Blackwell Publishing: Ames, IA, USA, 2003; p. 825. ISBN 9781118459751.

73. Desmet, P.J.J.; Govers, G. A GIS procedure for automatically calculating the USLE LS factor on topographically complex landscape units. J. Soil Water Conserv. 1996, 51, 427-433.

74. McCool, D.K.; Brown, G.R.; Foster, G.R.; Meyer, L.D. Revised Slope Steepness Factor for the Universal Soil Loss Equation. Am. Soc. Agric. Eng. 1987, 30, 1387-1396. [CrossRef]

75. Ramalho Filho, A.; Beek, K.J. Sistema de Avaliação da Aptidão Agrícola das Terras, 3th ed.; EMBRAPA-CNPS: Rio de Janeiro, Brazil, 1995. (In Portuguese)

76. Gasnari, B.P.; Ramesh, H. Assessment of Soil Erosion by RUSLE Model Using Remote Sensing and GIS-A Case Study of Nethravathi Basin. Geosci. Front. 2016, 7, 953-961. [CrossRef] 
77. Galdino, S. Estimativa da Perda de Terra sob Pastagens Cultivadas em Solos Arenosos da Bacia Hidrográfica do Alto Taquari-MS/MT. Ph.D. Thesis, Universidade Estadual de Campinas, Campinas, Brazil, 2012. (In Portuguese)

78. Oliveira, P.T.S.; Nearing, M.A.; Wendland, E. Orders of Magnitude Increase in Soil Erosion Associated with Land Use Change from Native to Cultivated Vegetation in a Brazilian Savannah Environment. Earth Surf. Process. Landf. 2015, 40, 1524-1532. [CrossRef]

79. Silva, M.A.; Silva, M.L.N.; Curi, N.; Oliveira, A.H.; Avanzi, J.C.; Norton, L.D. Water erosion risk prediction in eucalyptus plantations. Ciênc. Agrotecnol. 2014, 38, 160-172. [CrossRef]

80. Silva, B.P.C.; Silva, M.L.N.; Batista, P.V.G.; Pontes, L.M.; Araujo, E.F.; Curi, N. Soil and water losses in eucalyptus plantation and natural forest and determinantion of the USLE factors at a pilot sub-basin in Rio Grande do Sul, Brazil. Ciênc. Agrotecnol. 2016, 40, 432-444. [CrossRef]

81. Bertol, I.; Shick, j.; Batistela, O. Razão de perdas de solo e fator C para as culturas de soja e trigo em trêssSistemas de preparo em um cambissolo húmico alumínico. Rev. Bras. Ciênc. Solo 2001, 25, 451-461. (In Portuguese) [CrossRef]

82. Bertol, I.; Shick, J.; Batistela, O. Razão de perdas de solo e fator C para milho e aveia em rotação com outras culturas em três tipos de preparo de solo. Rev. Bras. Ciênc. Solo 2002, 26, 545-552. (In Portuguese) [CrossRef]

83. Weill, M.A.M. Estimativa da Erosão do Solo e Avaliação do seu Impacto na Microbacia do Ceveiro (Piracicaba, SP) Através do Índice de Tempo de Vida. Ph.D. Thesis, Universidade de São Paulo, Piracicaba, Brazil, 1999. (In Portuguese)

84. Prochnow, D.; Dechen, S.C.F.; de Maria, I.C.; Castro, O.M.; Vieira, S.R. Razão de Perdas de Terra e Fator C da Cultura do Cafeeiro em Cinco Espaçamentos, em Pindorama (SP). Rev. Bras. Ciênc. Solo 2005, 29, 91-98. [CrossRef]

85. Oliveira, A.M.M.D.; Pinto, S.D.A.F.; Lombardi Neto, F. Caracterização de Indicadores de Erosão do Solo em Bacias Hidrográficas com Suporte de Geotecnologias e Modelo Preditivo. Est. Geogr. 2007, 5, $63-86$. (In Portuguese)

86. Medeiros, G.O.R.; Giarolla, A.; Sampaio, G.; Marinho, M.A. Estimates of annual soil loss rates in the state of São Paulo, Brazil. Rev. Bras. Ciênc. Solo 2016, 40, 1-18. [CrossRef]

87. Gomes, L.; Simões, S.J.C.; Forti, M.C.; Ometto, J.P.H.B.; Dalla-Nora, E.L. Using geotechnology to estimate soil loss rate in the Brazilian Cerrado. J. Geogr. Inf. Syst. 2017, 9, 420-439. [CrossRef]

88. Gomes, L. Impacts of Land Use Changes on Soil Nitrogen Balance in the Brazilian Cerrado Region. Ph.D. Thesis, Earth System Science; National Institute for Space Research, São José dos Campos, Brazil, 2017.

89. Brazilian Institute of Geography and Statistics (IBGE). Rendimento Médio da Produção das Lavouras. Sistema IBGE de Recuperação Automática-SIDRA. Rio de Janeiro, 2000 (In Portuguese). Available online: http:/ / www2.sidra.ibge.gov.br/bda/tabela/listabl.asp?c=99\&z=t\&o=11 (accessed on 20 August 2017).

90. Brazilian Institute of Geography and Statistics (IBGE). Rendimento médio da produção das lavouras Sistema IBGE de Recuperação Automática-SIDRA. Rio de Janeiro, 2012 (In Portuguese). Available online: http: / / www2.sidra.ibge.gov.br/bda/tabela/listabl.asp?c=99\&z=t\&o=11 (accessed on 20 August 2017).

91. Statistical Yearbook of the Brazilian Association of Planted Forest Producers (ABRAF). Anuário Estatístico da ABRAF: Ano Base 2003; ABRAF: Brasília, Brazil, 2003. (In Portuguese)

92. Statistical Yearbook of the Brazilian Association of Planted Forest Producers (ABRAF). Anuário Estatístico da ABRAF: Ano Base 2012; ABRAF: Brasília, Brazil, 2013. (In Portuguese)

93. Brazilian Institute of Geography and Statistics (IBGE). Produção Agrícola Municipal. Sistema IBGE de Recuperação Automática-SIDRA; IBGE: Rio de Janeiro, Brazil, 2012; (In Portuguese). Available online: https:/ / sidra.ibge.gov.br/tabela/1612 (accessed on 5 October 2017).

94. Batjes, N.H.; Bernoux, M.; Cerri, C.E.P. Soil Data Derived from SOTER for Studies of Carbon Stocks and Change in Brazil (ver. 1.0; GEFSOC Project); Report 2004/03; ISRIC—World Soil Information: Wageningen, The Netherlands, 2004; p. 32.

95. Shagguan, W.; Dai, Y.; Duan, Q.; Liu, B.; Yuan, H. A global soil data set for Earth System modeling. J. Adv. Model. Earth Syst. 2014, 6, 249-263. [CrossRef]

96. Jolliffe, I.T. Principal Component Analysis; Series: Springer Series in Statistics; Springer: New York, NY, USA, 2002.

97. Shaw, P.J.A. Intoductory Multivariated Statistics for the Enviromental Science; Arnold: London, UK, USA, 2003. 
98. Manzatto, C.V.; Assad, E.D.; Baca, J.F.M.; Zaroni, M.J.; Pereira, S.E.M. Zoneamento Agroclimático da Cana-de-Açúcar: Expandir a Produção, Preservar a Vida e Garantir o Futuro; EMBRAPA Solos: Rio de Janeiro, Brazil, 2009. (In Portuguese)

99. FAO; IFAD; UNICEF; WPF; WHO. The State of Food Security and Nutrition in the World 2018. Building Climate Resilience for Food Security and Nutrition; FAO: Rome, Italy, 2018.

100. Amundson, R.; Berhe, A.A.; Hopmans, J.W.; Olson, C.; Sztein, A.E.; Sparks, D.L. Soil and human security in the 21st century. Science 2015, 348, 647-653. [CrossRef] [PubMed]

101. Telles, T.S.; Guimarães, M.F.; Dechen, S.C.F. The costs of soil erosion. Rev. Bras. Cienc. Solo 2011, 35, $287-298$. [CrossRef]

102. Schick, J.; Bertol, I.; Balbinot Junior, A.A.; Batistela, O. Erosão hídrica em cambissolo húmico alumínico submetido a diferentes sistemas de preparo e cultivo do solo: II. Perdas de nutrientes e carbono orgânico. Rev. Bras. Cienc. Solo 2000, 24, 437-447. (In Portuguese) [CrossRef]

103. Bertol, I.; Mello, E.L.; Guadagnin, J.C.; Zaparolli, A.L.V.; Garrafa, M.R. Nutrients losses by water erosion. Sci. Agric. 2003, 3, 581-586. [CrossRef]

104. Seganfredo, M.L.; Eltz, F.L.F.; Brum, A.C.R. Perdas de solo, água e nutrientes por erosão em sistemas de culturas em plantio direto. Rev. Bras. Cienc. Solo 1997, 21, 287-291. (In Portuguese)

105. Guadagnin, J.C.; Bertol, I.; Cassol, P.C.; do Amaral, A.J. Perdas de solo, água e nitrogênio por erosão hídrica em diferentes sistemas de manejo. Rev. Bras. Cienc. Solo 2005, 29, 277-286. (In Portuguese) [CrossRef]

106. Leon, J.; Osorio, N. Role of Litter Turnover in Soil Quality in Tropical Degraded Lands of Colombia. Sci. World J. 2014, 13. [CrossRef] [PubMed]

107. Scherr, S.J. The future food security and economic consequences of soil degradation in the developing world. In Response to Land Degradation; Oxford Press: New Delhi, India, 2001; pp. 155-170.

108. Valim, W.C.; Panachuki, E.; Pavei, D.S.; Sobrinho, T.A.; Almeida, W.S. Efeito de resíduos de vegetais de cana-de-açúcar no controle da erosão hídrica entressulcos. Ciências Agrárias 2016, 37, 1155-1164. (In Portuguese) [CrossRef]

109. Lal, R. Restoring soil quality to mitigate soil degradation. Sustainability 2015, 7, 5875-5895. [CrossRef]

110. Youlton, C.; Wendland, E.; Anache, A.a.; Poblete-Echeverria, C.; Dabney, S. Changes in erosion and runoff due to replacement of pasture land with sugarcane crops. Sustainability 2016, 8, 685. [CrossRef]

111. Gomez, J.D.P. Estimativa de Erosão pela Equação Universal da Perda de Solo (USLE) e Transferência de Sedimentos Para todo Território Brasileiro. Master's Thesis, Universidade de São Paulo, Piracicaba, Brazil, 2012. (In Portuguese)

(C) 2019 by the authors. Licensee MDPI, Basel, Switzerland. This article is an open access article distributed under the terms and conditions of the Creative Commons Attribution (CC BY) license (http://creativecommons.org/licenses/by/4.0/). 